\title{
Limbal Stem Cell Deficiency: Current Treatment Options and Emerging Therapies
}

\author{
Michel Haagdorens, ${ }^{1,2,3}$ Sara Ilse Van Acker, ${ }^{1}$ \\ Veerle Van Gerwen, ${ }^{1}$ Sorcha Ní Dhubhghaill, ${ }^{1,2}$ Carina Koppen, ${ }^{1,2}$ \\ Marie-José Tassignon, ${ }^{1,2}$ and Nadia Zakaria ${ }^{1,2,4}$ \\ ${ }^{1}$ Faculty of Medicine and Health Sciences, Department of Ophthalmology, Visual Optics and Visual Rehabilitation, \\ University of Antwerp, Campus Drie Eiken, T building, T4-Ophthalmology, Universiteitsplein 1, 2610 Antwerp, Belgium \\ ${ }^{2}$ Department of Ophthalmology, Antwerp University Hospital, Dienst Oogheelkunde, Wilrijkstraat 10, 2650 Edegem, Belgium \\ ${ }^{3}$ Research Foundation-Flanders, Egmontstraat 5, 1000 Brussels, Belgium \\ ${ }^{4}$ Center for Cell Therapy and Regenerative Medicine, Antwerp University Hospital, CCRG-Oogheelkunde, \\ Wilrijkstraat 10, 2650 Edegem, Belgium
}

Correspondence should be addressed to Michel Haagdorens; michelhaagdorens@gmail.com

Received 19 June 2015; Accepted 18 August 2015

Academic Editor: Kequan Guo

Copyright ( $) 2016$ Michel Haagdorens et al. This is an open access article distributed under the Creative Commons Attribution License, which permits unrestricted use, distribution, and reproduction in any medium, provided the original work is properly cited.

\begin{abstract}
Severe ocular surface disease can result in limbal stem cell deficiency (LSCD), a condition leading to decreased visual acuity, photophobia, and ocular pain. To restore the ocular surface in advanced stem cell deficient corneas, an autologous or allogenic limbal stem cell transplantation is performed. In recent years, the risk of secondary LSCD due to removal of large limbal grafts has been significantly reduced by the optimization of cultivated limbal epithelial transplantation (CLET). Despite the great successes of CLET, there still is room for improvement as overall success rate is $70 \%$ and visual acuity often remains suboptimal after successful transplantation. Simple limbal epithelial transplantation reports higher success rates but has not been performed in as many patients yet. This review focuses on limbal epithelial stem cells and the pathophysiology of LSCD. State-of-the-art therapeutic management of LSCD is described, and new and evolving techniques in ocular surface regeneration are being discussed, in particular, advantages and disadvantages of alternative cell scaffolds and cell sources for cell based ocular surface reconstruction.
\end{abstract}

\section{Introduction}

Located at the anterior segment of the eye, the cornea is highly organised transparent tissue consisting of multiple cellular and noncellular layers [1]. The corneal epithelium covers the corneal surface and plays a major role in protection and transparency $[2,3]$. Epithelial cells are shed regularly and replaced by stem cell sources located at the limbus, a rim of tissue located at the junction of the cornea and sclera (Figures $1(\mathrm{~A})$ and $1(\mathrm{~B})$ ). The limbal epithelial stem cells (LESCs) reside in specific regions at the limbus known as the limbal stem cell niches [4]. Damage to the stem cells or disruption of the niches may lead to Limbal Stem Cell Deficiency (LSCD). In the absence of a healthy corneal epithelium, the conjunctiva proliferates over the cornea resulting in opacification and vascularization, which in turn may lead to reduced vision, pain, and photophobia $[5,6]$. LSCD can be caused by a wide variety of primary and secondary causes (Table 1) but is most frequently seen associated with severe chemical or thermal burns.

Diagnosis of LSCD is often on the bases of history and clinical findings, which include loss of limbal anatomy, corneal conjunctivalization, persistent epithelial defects, and scar formation [7, 8]. In partial LSCD clinical signs are present but limited to specific regions, which may be quantified by the number of limbal clock hours involved. The diagnosis is confirmed by impression cytology [9], illustrating the presence of goblet cells, increased cytokeratin 


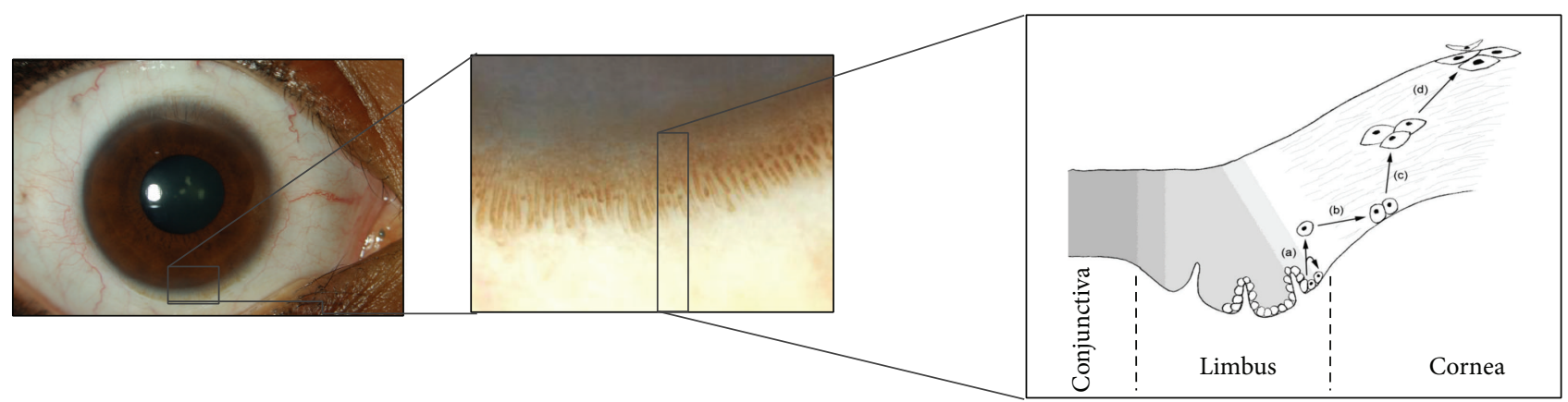

(A)

(B)

(C)

Figure 1: (A) Overview of the anterior surface of the human eye, in which the sclera (with overlying conjunctiva) and cornea can easily be discriminated. (B) The limbus is highly pigmented in some individuals, and allows clear visualization of the limbal palisades of Vogt. The cornea (and underlying dark iris) is pictured above, and conjunctiva (and underlying sclera) below. (C) Diagram of a cross section through the conjunctival, limbal and corneal epithelium. Limbal progenitor cells (a) differentiate into transient amplifying cells (b), post-mitotic cells (c) and finally terminally differentiated cells (d). Movement of cells in X, Y, Z direction is presented by proliferation of stem cells(a), differentiation and centripetal migration $(b, c)$, and desquamation $(d)$ respectively.

TABLE 1: Aetiology of LSCD.

\begin{tabular}{lr}
\hline Primary causes & Reference \\
\hline Aniridia & {$[67,71,72]$} \\
Multiple endocrine deficiency & {$[9,67]$} \\
Epidermal dysplasia & {$[73]$} \\
Ectrodactyly-ectodermal-dysplasia-clefting syndrome & {$[74]$} \\
Congenital erythrokeratodermia & {$[75,76]$} \\
Dyskeratosis congenita & {$[67,77]$} \\
\hline Secondary causes & {$[67,78]$} \\
\hline Thermal or chemical burns & {$[67]$} \\
Contact lens wear & {$[79]$} \\
Inflammatory eye disease: & {$[80]$} \\
Stevens-Johnson syndrome, toxic epidermal necrolysis & {$[80]$} \\
Ocular cicatricial pemphigoid & {$[81]$} \\
Chronic limbitis: autoimmune disease, extensive microbiological infection, atopic conjunctivitis & {$[82]$} \\
Neurotrophic keratitis & {$[83,84]$} \\
Extensive limbal cryotherapy, radiation, or surgery & {$[85]$} \\
Bullous keratopathy & \\
Topical antimetabolites (5-FU, Mitomycin C) & \\
Systemic chemotherapy (Hydroxyurea) &
\end{tabular}

5-FU: 5-fluorouracil.

19 (CK19) expression, and reduced CK3/12 expression [10]. More recently CK7, mucinl, and mucin5AC have been reported as more specific than CK19 for diagnostic purposes [11-14].

In vivo confocal microscopy (IVCM) and anterior optical coherence tomography (OCT) are promising techniques that may assist in diagnosing and quantifying LSCD and guiding therapeutic management. IVCM provides high-resolution images of anatomical structures at the cellular level $[15,16]$. A number of practical factors limit its use; firstly there is no consensus on the definitive morphological appearance of LESCs, surrounding niche cells or goblet cells on IVCM [17, 18]. Secondly, in the presence of a hazy cornea, the technique is less effective in defining structures due to high degree of backscatter, and finally it requires the prolonged cooperation of the patient [19]. Anterior OCT, and in particular Fourier Domain OCT (FD-OCT), is a more rapid and convenient method of imaging limbal, scleral, and conjunctival structures, though, with significantly lower resolution than IVCM [20]. 3D guided reconstructions of the limbus can be made and may assist guided limbal biopsy [20]. Furthermore, FDOCT can be applied in imaging hazy corneas and facilitates intraoperative dissection of fibrovascular pannus.

\section{Treatment of LSCD}

Therapeutic options for LSCD range from conservative to invasive and depend on the severity of the pathology 


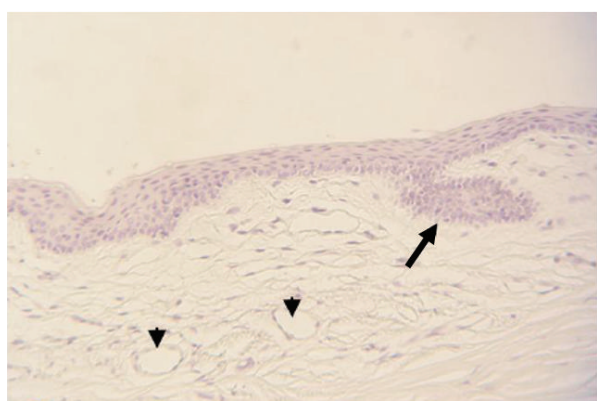

(a)

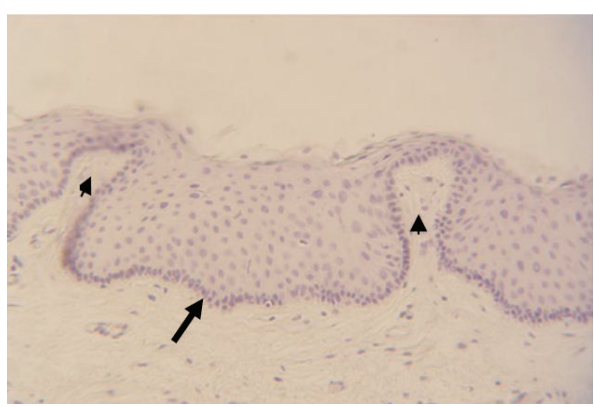

(b)

FIGURE 2: Haematoxylin staining of cross section through normal limbal region. Arrow in (a) indicates a LESC containing limbal epithelial crypt; arrowheads indicate blood vessels. Arrow in (b) indicates a limbal crypt, flanked by two focal stromal projections (arrowhead).

(Table 2). Conservative therapeutic options include supportive management, corneal scraping, and amniotic membrane patching. In these cases, recovery depends on the presence of some remaining LESCs that can be rehabilitated to restore the epithelium. If there are no remaining stem cell reserves, the cornea must be reseeded with new LESCs [7, 21]. Over the past 18 years, optimizing reseeding techniques has been a major focus of corneal tissue engineering. The earliest techniques required large sections of donor tissue either from the patient's fellow eye (autograft) or from a healthy donor or cadaver (allograft). Taking such large biopsies places the donor eye at risk of developing LSCD. In 1997, Pellegrini et al. reported the first application of ex vivo expansion of a very small stem cell biopsy in the treatment of LSCD [22]. The ex vivo technique significantly reduced the risk to the donor eye. Since the original report, numerous clinical trials have reported outcomes of tissue engineered corneal surface reconstruction [22-60]. This review will focus on the nature of LESCs and the evolution and optimization of cultivated limbal epithelial stem cell transplantation (CLET) as well as possible future directions.

\section{Limbal Epithelial Stem Cell Niches and Markers}

A stem cell niche is the unique microenvironment that surrounds stem cells and modulates their function and fate through internal and external factors. LESCs reside in a such well-protected microenvironment, the limbal stem cell niche. The niches are protected from UV-radiation by (i) melanocytes that reside in the basal layers of the limbal epithelium and (ii) the upper and lower eyelid that offer cover to the superior and inferior limbus $[8,61,62]$. The niche's undulated basement membrane protects LESCs from shear force, whereas limbal stromal blood vessels and mesenchymal cells supply it with oxygen, cytokines, growth factors (e.g., the keratinocyte growth factor), and other nutrients $[16,63-$ $65]$. The niche also regulates the LESC cell cycle to keep them in an undifferentiated resting state $[16,66]$. Proliferation of a LESC gives rise to two daughter cells, where one remains an oligopotent LESC and the other differentiates into a transient amplifying cell (TAC). After a high but limited number of mitoses, TACs differentiate into "postmitotic cells" and subsequently "terminally differentiated cells" [6769] (Figure $1(C)$ ). During this differentiation process, cells migrate centripetally from the niche to the corneal surface [4] according to the $X Y Z$-hypothesis [70], that is, proliferation of basal epithelial cells $(x)$, differentiation and centripetal migration $(y)$, and isolation/desquamation $(z)$.

Recently, Molvaer et al. localized and described the three different limbal stem cell niches, (i) the limbal epithelial crypts (LECs), (ii) the limbal crypts (LCs), and (iii) the focal stromal projections (FSPs) (Figure 2) [98]. LECs were first described in 2005 as projections extending from the undersurface of the limbal epithelium into the stroma. These projections extend radially into the conjunctival stroma parallel to the palisade or circumferentially along the limbus at right angles to the palisade (Figure 2(a)) [99]. In 2007, LCs and FSPs were described as additional stem cell niches. LCs are projections of the limbal epithelium into the stroma, which are laterally enclosed by the palisades of Vogt [16]. The defined area corresponds in part to the previously described interpalisades (Figure 2(b)). FSPs are finger-shaped projections of stroma containing a central blood vessel, which extend upward into the limbal epithelium [16]. More recently, a further subdivision was made between basal and superficial LCs, the former containing LESCs with melanocytes, the latter containing TACs [100]. It has been proven that all three limbal stem cell niches are mainly present at the superior, and to lesser extent, the inferior limbus. There is no consensus, however, about the exact number and location of niches in the limbus [98].

Stemness and differentiation of LESCs have been investigated through the analysis of various cell markers. Though no specific marker for LESCs has been identified [101, 102], ABCG2 (also known as BRCP1) [103], p63 $\alpha$ [104], and $\Delta$ Np63 [105] isoforms are the leading markers used in putative LESC identification. Additional stem cell markers have been described, with integrins $\alpha \mathrm{v} \beta 3 / 5$ and the ABCB5 gene most recently [106, 107]. Ordonez et al. identified integrin $\alpha \mathrm{v} \beta 3 / 5$ in less than $4 \%$ of cells present in the limbal epithelial niche. However, these cells had phenotypic and functional LESC properties [106]. 


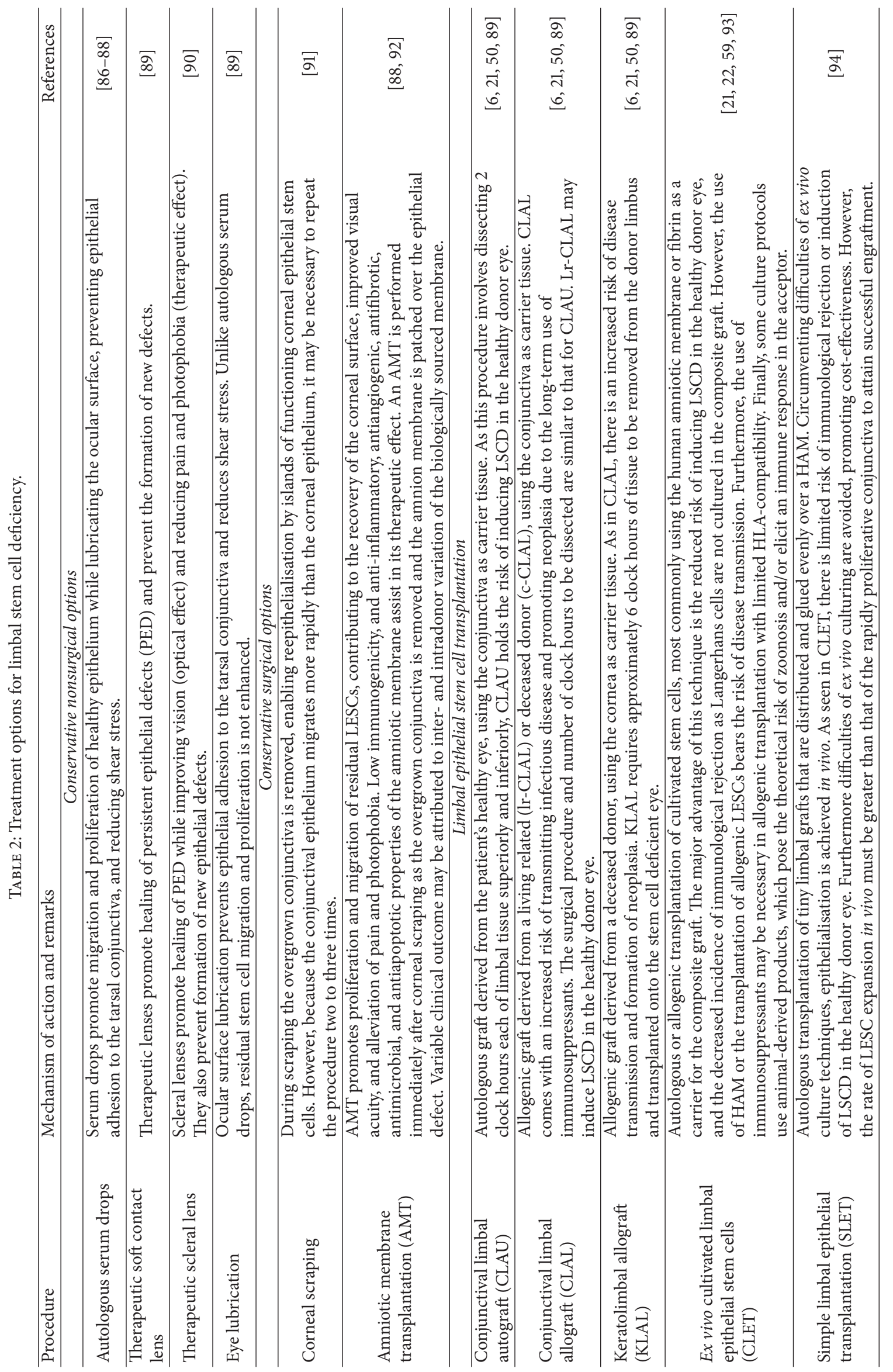




\section{Cultured Limbal Epithelial Stem Cell Transplantation}

As a technique, cultured limbal epithelial stem cells transplantation (CLET) is in its infancy. The overall success rate is estimated to be $76 \%$ [21], though direct comparison of clinical trials is difficult due to the wide diversity of pathologies treated, culture protocols, surgical approach, and subjective and objective outcome parameters. When recently published clinical reports are taken into account, success rate decreases slightly to $70 \%$. Details on culture methods and clinical results of published reports are described (Table 3). No significant differences were found in the clinical outcomes based on initial cause of LSCD, source of donor tissue (autologous or allogenic), or culture technique (explants or suspension) [21, 93]. Some culture protocols require the use of lethally irradiated or Mitomycin C-treated 3T3 feeder cells, either in direct contact or in coculture with the LESCs [25, $29,31,35,37,41-45,47,50-52,55,58-60]$. The feeder layers are involved in promoting niche regulation and stemness of cultivated cells. Though no adverse reactions have been reported in the use of 3T3 feeder layers in large case series $[108,109]$, avoiding xenogenic material may help reduce the risk of animal-derived infection and graft rejection. The search for alternatives to bovine and other animal products in cultivation protocols, for example, fetal bovine serum and animal-derived growth factors, has led to recent clinical studies cultivating LESCs under nonxenogenic conditions $[52,54,55,57-59]$. Other advances in the field that may also translate to a higher success rate in future trials include feeder layers of human fibroblasts or Mesenchymal Stem Cells (MSCs) [110-114], standardized GMP (Good Manufacturing Practice) protocols [115] for HAM preparation and ex vivo culture, use of autologous serum drops postoperatively, and minimal manipulation of the graft during transplantation [116-118].

In 2012, simple limbal epithelial transplantation (SLET) was described as a novel surgical technique for the treatment of unilateral LSCD [94]. During SLET surgery, a small strip of donor limbal tissue (e.g., $2 \times 2 \mathrm{~mm}$ ) is divided into several smaller pieces, which are then distributed evenly over a HAM placed on the cornea [94]. The surgery obviates the need for a culture protocol entirely. Although each clinical study reported a success rate of $100 \%$ in a small case series (Table 4) [94-97, 119, 120], the long-term effectiveness of the technique is yet to be proven.

\section{Alternative Cell Carriers}

In clinical trials, HAM is the most commonly used cell carrier for ocular surface reconstruction [23-27, 29-33, 35$42,44,45,47,48,50-60]$. However, there are risks associated with the use of HAM including possible transfer of infectious agents, variable tissue quality, and limited transparency, which is why alternative seeding scaffolds have been proposed $[42,121]$.

5.1. Modified HAM. Chemical crosslinking of HAM may enhance mechanical and thermal stability, optical transparency, and resistance to collagenase digestion [122-126].
The crosslinking agents that have been investigated are Glutaraldehyde, (L-Lysine-modulated) Carbodiimide, and $\mathrm{Al}_{2}\left(\mathrm{SO}_{4}\right)_{3}$ [122-126]. In vitro experiments showed that Glutaraldehyde conferred a higher degree of cytotoxicity than Carbodiimide [123], whereas the addition of L-lysine to the Carbodiimide crosslinking enhanced mechanical and thermal strength, the ability to support LESCs, and resistance to enzymatic digestion, though higher concentrations could compromise transparency and biocompatibility [126].

5.2. Collagen. Collagen is the main extracellular matrix protein of the cornea and has been widely investigated in the development of biomimetic carrier materials. It is naturally biocompatible and relatively inexpensive to isolate $[127,128]$. LESCs can be successfully cultivated on collagen carriers, while maintaining normal phenotype and achieving multilayered stratification when transplanted in vivo [127, 129, 130]. Cell attachment and proliferation can be further improved, by coating scaffolds with extracellular matrix proteins (e.g., laminin, type IV collagen, and fibronectin) or derivative adhesion peptides (e.g., YIGSR, IKVAV, and RGC) [131-137]. Most experimental studies have been performed using animal-derived collagen (e.g., porcine collagen type I, rat tail collagen type I, bovine dermal collagen, and fish scale) $[127,138-144]$. This collagen may transmit diseases or induce immune reactions, and therefore the more expensive recombinant human collagen (RHC) type I and type III are being investigated further for clinical translation [145-151]. Despite the advantages associated with their use, collagen hydrogels are inherently weak due to the high water content [152]. Several methods have been proposed to improve the mechanical properties of collagen hydrogels.

5.2.1. Chemically Crosslinked Collagen. Griffith et al. have reported the construction of biosynthetic collagen scaffolds consisting of concentrated type I and type III RHC solutions, crosslinked with 1-ethyl-3-(3-dimethyl aminopropyl) Carbodiimide (EDC) and N-hydroxysuccinimide (NHS) [153155]. When LESCs were cultivated in vitro on the optically transparent constructs, a stratified epithelium formed and covered the surface within three weeks. The constructs were sufficiently robust to provide adequate mechanical stability and elasticity for surgical manipulation. Type III collagen hydrogels tended to be mechanically superior. In vivo verification and validation showed that the acellular scaffolds stayed optically clear and promoted regeneration of corneal cells, nerves, and tear film, without the need for longterm immunosuppression [149]. However, the mechanical properties of the constructs were significantly lower than human corneas and the long-term stability still needs to be ascertained.

To improve the mechanical properties of the constructs, Griffith et al. have investigated reinforced membranes fabricated from EDC/NHS crosslinked type III RHC and PEG-diacrylate crosslinked 2-methacryloyloxyethyl phosphorylcholine (MPC) [151, 156-158]. These hydrogels showed increased mechanical strength and stability against enzymatic digestion and UV degradation and promoted corneal cell and nerve regeneration while optical properties were 


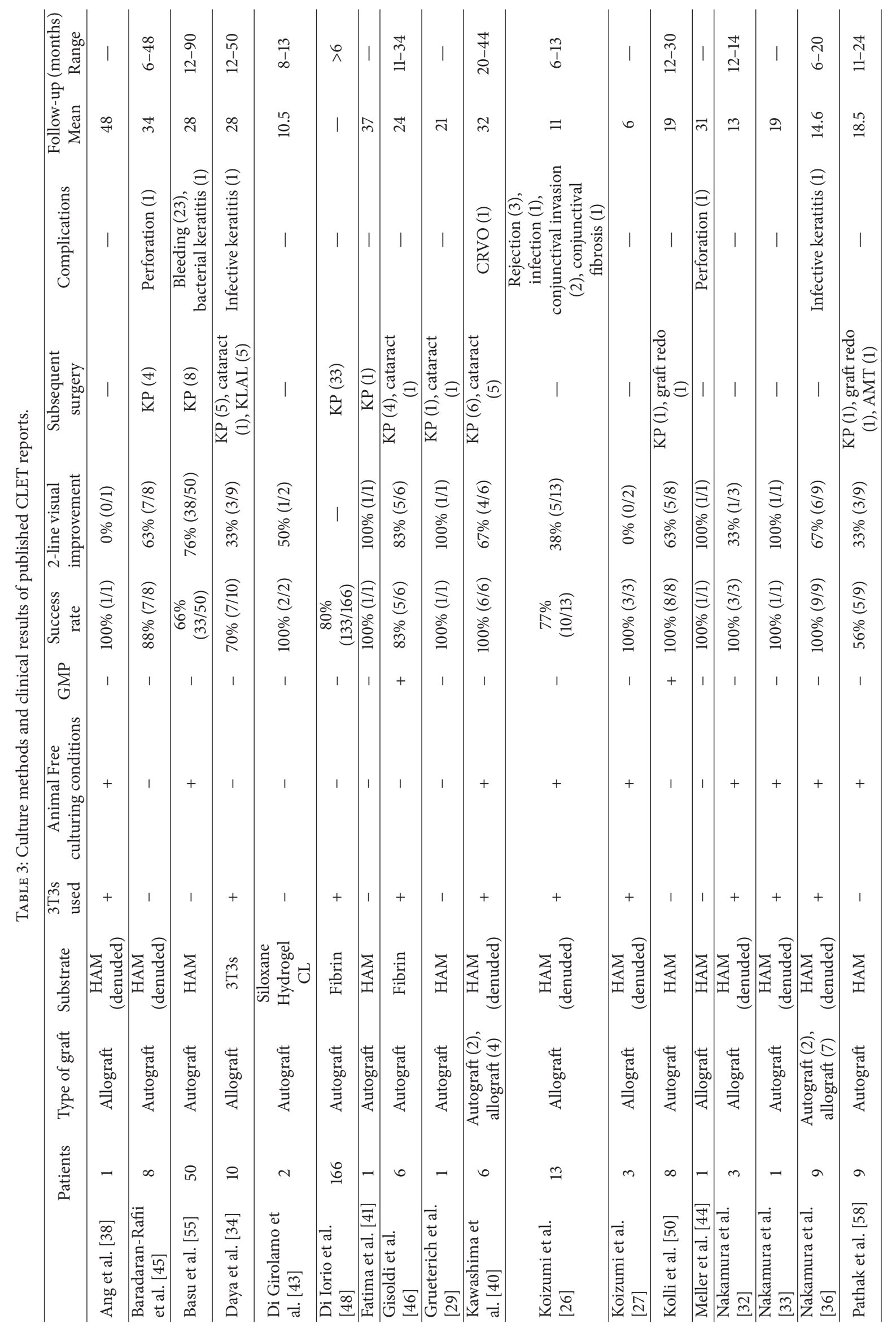




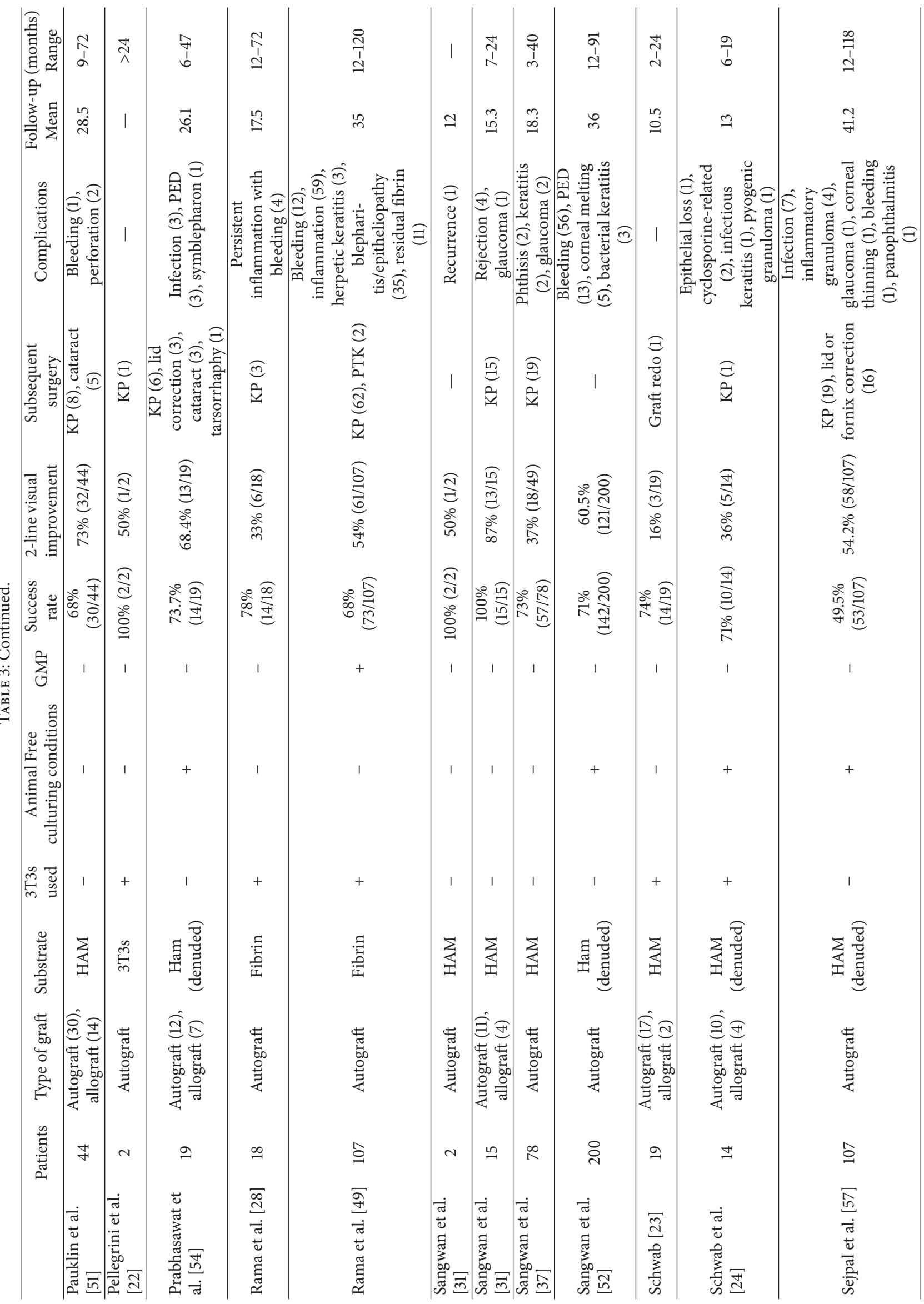




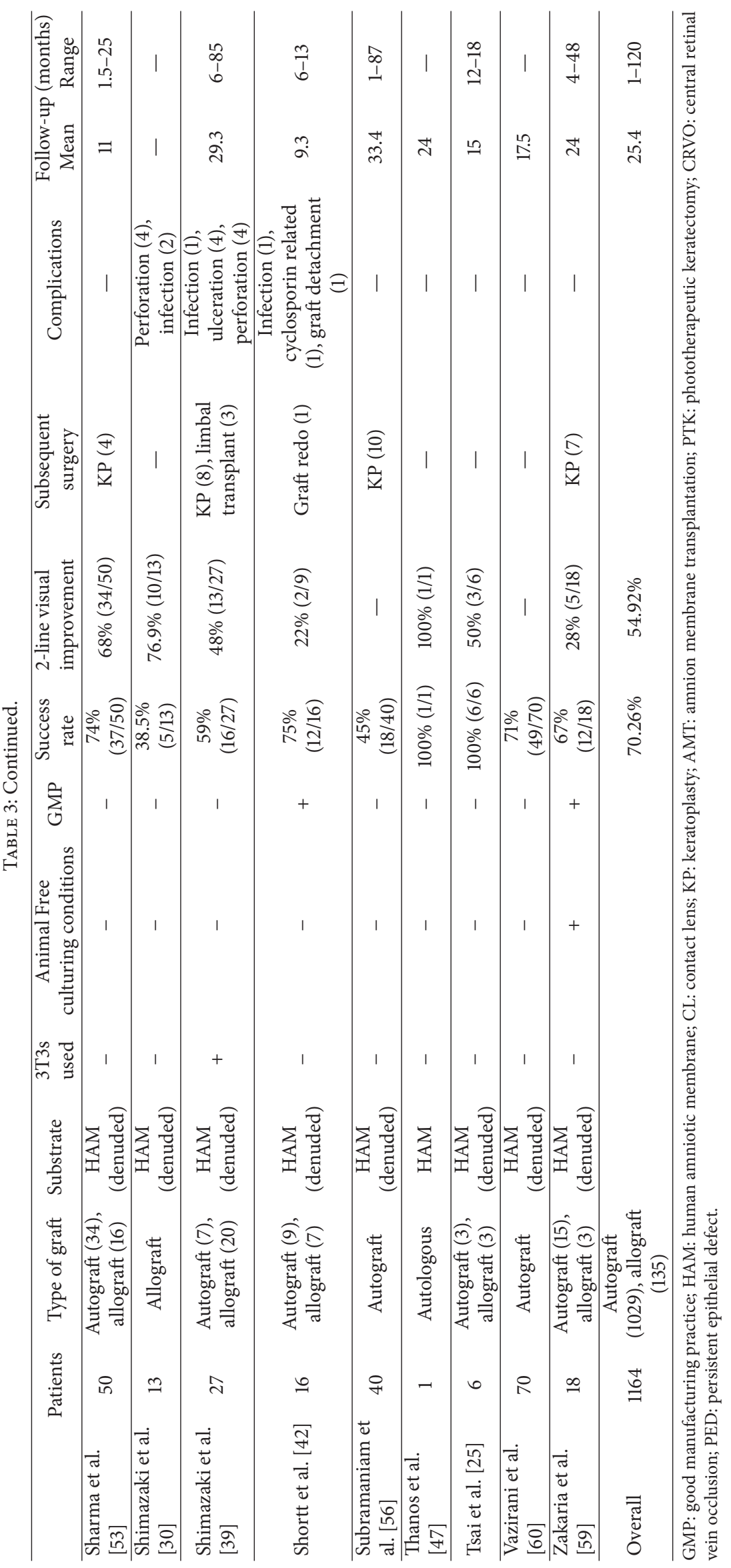




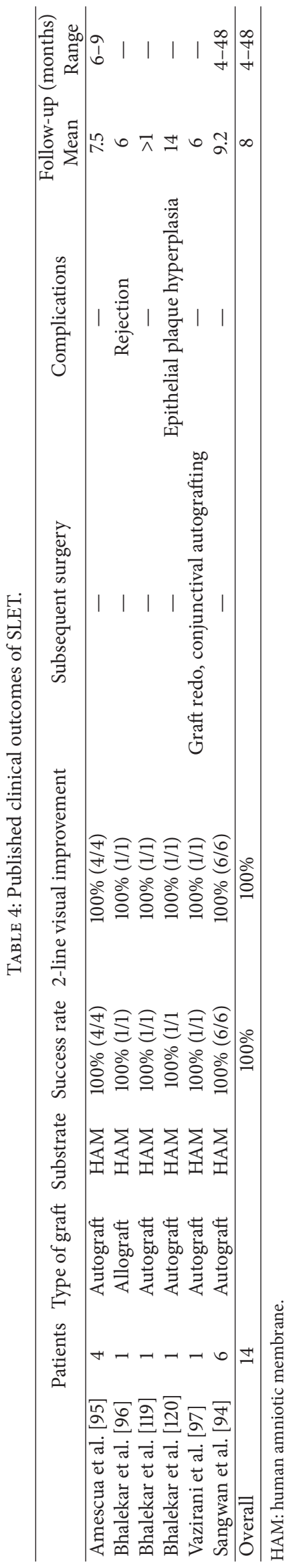


comparable to a normal cornea [156]. Cell-free RHC-MPC implants have been grafted in 7 eyes, in which patients showed stable epithelia 12 months postoperatively and the best corrected vision improved by $1-2$ lines $[151,158]$. Another form of collagen hydrogel, genipin-crosslinked chitosancollagen and PEG-Carbodiimide chitosan-collagen hydrogel, has also been examined for ocular surface reconstruction [139, 159]. In vitro experiments with these constructs show maintenance of regular stratified multilayered epithelium [159], while initial animal testing shows good biocompatibility [139]. Use in human corneal regeneration has not yet been reported.

5.2.2. Plastic Compression Collagen. In 2010, Mi et al. improved the mechanical strength of collagen hydrogels by compressing and blotting the constructs between paper sheets and a nylon mesh thereby reducing the water content of the gels [160]. LESCs cultivated on this construct displayed a smooth and homogenous morphology, whereas cells cultured on conventional hydrogels were distributed more heterogeneously. Subsequent studies confirmed that plastically compressed collagen gels are optically transparent and easy to handle, had improved mechanical strength, and support LESC adhesion, proliferation, and stratification [160-163]. Mechanical strength could further be improved by photochemical crosslinking [164]. Kits that enable the production of $3 \mathrm{D}$ plastic compressed cultures have recently become commercially available (RAFT, TAP Biosystems, Hertfordshire, UK).

5.3. Fibrin. Fibrin is the biodegradable product formed during coagulation. Fibrin membranes can be fabricated by combining fibrinogen and thrombin, both harvested from human plasma. Fibrin derivates have been used extensively in ophthalmology, typically as a glues or membranes [165-168].

Four clinical studies have reported the use of fibrin as a substrate in CLET surgery [28, 46, 48, 49]. In animal studies, fibrin gels were found to degrade completely after 3 days [169]. After gel degradation, the transplanted cells adhered directly to the host corneal stroma. In early 2015, Holoclar (Chiesi, Italy) has been conditionally approved to be released in Italy as the first commercially available stem cell therapy for LSCD treatment. Existing data on Holoclar have been obtained by retrospective patient follow-up, and annual renewal of approval will be guided by results of a current multicenter, prospective phase IV clinical trial. Nevertheless, practical use of this fibrin-based Advanced Therapeutic Medicinal Product (ATMP) is limited to autologous stem cell transplantation in unilateral cases after chemical or thermal burn. Notably, the technique still utilizes lethally irradiated murine 3T3J2 fibroblast feeder cells and bovine serum during graft generation, which brings into question the safety of the xenobased cell product [49].

5.4. Siloxane Hydrogel Contact Lenses. In the initial CLET clinical trial by Lu et al., a 3T3 cocultured human epithelial sheet was mounted on a soft contact lens, prior to transplantation as a carrier [170]. In a subsequent study by Di Girolamo et al., the LESCs were cultivated directly on the contact lens
[171]. Gore et al. investigated cultivation of LESCs on contact lenses that were coated with a 3T3 feeder layer [172]. In this study, in vitro cultivated LESCs formed a multilayered corneal epithelium, while some basal cells maintained their stemness. Plasma polymer-coated contact lenses also promoted in vitro LESC adhesion and proliferation [173]. Transplantation of these LESCs in a LSCD rabbit model gave rise to patches of stratified epithelium; however, recipient corneas showed only partial reconstruction, possibly due to short-term follow-up (26 days).

5.5. Poly( $\varepsilon$-caprolactone). Poly( $\varepsilon$-caprolactone) is a highly flexible and strong material that has already been used as a scaffold for skin, bone, and MSC applications. The biocompatibility and optical transparency of $\operatorname{poly}(\varepsilon$-caprolactone) may be improved by electrospinning and surface modification, and such modified sheets can support LESC cultivation [174]. The in vivo use of the material has not yet been reported.

5.6. Chitosan-Gelatin. Chitosan is a stiff crystalline polysaccharide that is extracted from chitin from arthropod exoskeletons. Membranes of pure chitosan are too stiff for ocular purposes but the addition of gelatine and crosslinkers can improve the material handling [175]. Chitosan-gelatine membranes have extensively been investigated for regeneration of bone, cartilage, and skin [176-178]. Chitosangelatin membranes with a $20: 80$ ratio supported the growth of LESCs that expressed CK3/12, CK15, and ABCG2 [179]. Again, the in vivo use of this material has not been reported.

5.7. Silk Fibroin. Silk fibroin (SF), obtained from Bombyx mori (domesticated silkworm), can be processed into thin transparent membranes. It is nonimmunogenic, degradable, mechanically strong, and optically transparent and has been used as suture material and in bone and cartilage regeneration [180-182]. Cultivation of LESCs on nonporous SF films gives rise to a stratified corneal-like epithelium [183187]. Porous SF membranes can be developed by mixing SF and poly(ethylene glycol) (PEG) and have supported LESC growth [183] although results have varied [186]. It may be possible to coculture MSCs within pores to recreate the stromal microenvironment [186]. SF may also be combined with chitosan (SF-CS) and the constructed scaffolds have been investigated with some success $[188,189]$. LESCs that were seeded on such lamellar corneas were comparable to native tissue, as outgrown cells had physiological morphology and high levels of CK3/12 expression [189]. Furthermore, biocompatibility of SF and SF-CS films has been observed in rabbit corneas for up to six months [183, 188]. However, membranes constructed from SF derived from Antheraea pernyi (wild silkworm) proved to be more prone to becoming opaque, displayed lower permeability, and were more brittle than conventional nonporous SF films [187].

5.8. Human Anterior Lens Capsule. The Human Anterior Lens Capsule (HaLC) is a dense membrane consisting of Collagen IV, laminin, and heparin sulphate proteoglycans. HaLC is characterized by a gradually increasing thickness 
$( \pm 0.35 \mu \mathrm{m}$ per year) and simultaneous loss of mechanical strength $( \pm 1 \%$ each year) $[190,191]$. LESCs have been successfully cultivated on HaLCs, with in vitro viability of $>95 \%$; cell density and cell morphology were similar to LESCs cultivated on plastic [192]. LESCs, cultured under nonxenogenic conditions maintained their oligopotency, while some cells showed directional differentiation into corneal epithelium [193]. This promising alternative scaffold needs further in vivo verification. Concern has been raised, however, that the diameter of extracted HaLC may not be large enough for corneal treatments [192].

5.9. Keratin. Reichl et al. succeeded in fabricating a transparent membrane from keratin extracted from human hair [194]. LESC behavior on the films was similar to that on HAM and was not affected by prior plasma treatment sterilization of the material [195]. Unfortunately, suturing is impaired by a high rate of suture tear-out [195].

5.10. Poly(lactide-co-glycolide). Poly(lactide-co-glycolide) (PLGA) is an FDA-approved, biodegradable, and noncytotoxic material that has been used in products such as dissolvable sutures [196]. Transparent electrospun PLGA scaffolds are easy to handle, store, and suture [197]; however when LESCs were cultivated on these carriers, the scaffolds began to disintegrate in vitro and were fragile to handle. Additional research has shown that PLGA can be chemically altered to achieve predictable and slower breakdown, both in vitro and in vivo $[198,199]$. Disintegration was now evident by two weeks after initiation of LESC cultivation, with complete breakdown occurring by six weeks in vitro [199].

5.11. Polymethacrylate. Polymethacrylate has been used in ophthalmology to produce rigid intraocular lenses and contact lenses. It can be fabricated into transparent biocompatible hydrogels, which can support LESC proliferation [200, 201]. Augmenting the polymethacrylate with 1,4diaminobutane has been shown to improve LESC adherence and proliferation [202].

5.12. Hydroxyethylmethacrylate. Hydroxyethylmethacrylate and poly-2-hydroxyethylmethacrylate have been used to manufacture soft contact lenses, the Chirila Kpro and the AlphaCor (Addition Technology Inc., Des Plaines, IL) [203, 204]. One study has investigated hydroxyethylmethacrylate in ocular surface reconstruction and concluded that LESCs and fibroblasts could adhere and proliferate to hydroxyethylmethacrylate hydrogels that were surface modified with type I collagen and arginine-glycine-aspartic acid ligand [205].

5.13. Poly(ethylene glycol). PEG is a biocompatible polymer used in pharmaceutical products (e.g., capsules, tablet binders, ointments, and slow release medications). Transparent hydrogels based on PEG-diacrylate and PEG-diacrylamide have been used in vivo and showed favourable results for the latter as PEG-diacrylate implants showed inflammation, corneal haze, and corneal ulceration. Rabbits with PEGdiacrylamide implants, on the other hand, remained healthy and had clear corneas and noninflamed eyes for up to 6 months after transplantation [206, 207]. In vitro experiments showed that photolithographical surface coating with collagen type I was necessary to allow LESC adhesion and proliferation [208]. PEG-diacrylate and PEG-diacrylamide hydrogels were intended for full thickness corneal regeneration; however, thinner gels intended for anterior corneal regeneration are yet to be investigated. PEG has also been combined with chitosan and silk fibroin to make even stronger and more transparent biomaterials [209].

5.14. Platelet Poor Plasma. Platelet-Poor Plasma (PPP) is blood plasma with very low numbers of thrombocytes $(<10 \times$ $\left.10^{3} / \mu \mathrm{L}\right)$, which are removed by centrifugation. Biodegradable, transparent PPP membranes can be manufactured to function as a seeding scaffold in autologous and allogenic CLET. LESC allografts mounted on autologous PPP sheets in LSCD rabbits improved corneal transparency and resulted in a multilayered CK3/12+ epithelium [210, 211].

5.15. Poly(vinyl alcohol). Poly(vinyl alcohol) is a transparent hydrogel with good mechanical strength. Poly(vinyl alcohol) shows low cell affinity, but when incorporated with collagen type I it can support a fully stratified corneal epithelium in vitro [212], but to support in vivo epithelialization poly(vinyl alcohol)-collagen requires the assistance of HAM [213].

\section{Carrier-Free Transplantation}

Nishida et al. reported a temperature-responsive polymer, that is, poly( $N$-isopropylacrylamide) (PIPAAm), that could release intact, transplantable epithelial sheets that retain stem cells and epithelial cells [214]. The copolymer PIPAAmPEG is at present commercialized as Mebiol gel and is hydrophilic at temperatures below $20^{\circ} \mathrm{C}$ and hydrophobic at temperatures above. Experiments have shown that Mebiol supports LESC cultivation in vitro and that autologous CLET in Mebiol restores the ocular epithelial surface in a LSCD rabbit model. The particular properties of Mebiol gel allow for easy graft transplantation. Drops of cooled Mebiol gel containing cultured LESCs can be applied to the ocular surface and a contact lens placed over it to keep it in place [215].

Furthermore, in vitro fibrin degradation, biodegradable type I collagen, and centrifugation proved to be effective techniques in fabricating carrier-free epithelial sheets. Cultured cells did proliferate and differentiate under the respective conditions, and cell-survival in the subsequent carrier-free state was preserved [216-218].

\section{Alternative Cell Populations}

LSCD frequently manifests as a bilateral condition where no residual stem cells are available for ex vivo culture. Allograft material from living related donors or cadavers may be used, but this is associated with an increased risk of disease transmission, rejection, and neoplasia (associated with immunosuppressive agents). Alternative cell populations could potentially replace the use of allogenic material 
and within the last decade a number of approaches have been explored with varying success [219].

7.1. Oral Mucosal Epithelial Cells. In 2003, Nakamura et al. described Cultivated Oral Mucosal Epithelial Transplantation (COMET) in a rabbit animal model [220]. Oral Mucosal Epithelial Cells (OMECs) are cultured on a HAM until a stratified epithelium is attained and then transplanted. The construct mimics the corneal epithelium as transplanted stem cells maintain their stemness at the ectopic site, and OMECs acquire corneal epithelial-like markers such as CK3, CK19, Ki-67, p63, p75, and cornea-specific PAX6 and CK12 [221223]. COMET has been successful (i.e., regenerating a totally epithelized, stable, and avascular corneal surface) in patients with severe total LSCD [221, 223-232]. However, transplanted cultivated sheets are not completely identical to in vivo corneal epithelium, which leads to a variable degree of in vivo keratinization and stratification (up to 12 cell layers) [221, 228]. Small case series favour CLET, as COMET is associated with higher rates of peripheral corneal neovascularisation, inferior best corrected visual improvement, and increased risk of dry eye conditions postoperatively [221, 228].

7.2. Conjunctival Epithelial Cells. Human conjunctival epithelial cells grown on HAM have been used to reconstruct the ocular surface in rabbits with LSCD [233]. The transplanted conjunctival call sheets formed a five- to six-layer epithelium that remained transparent, smooth, avascular, and without epithelial defects [234]. Transplanted cells keep expressing both conjunctival (CK4) and corneal epithelial markers (CK3/12). Human conjunctival epithelial cell transplantation has been used clinically [235] and in one study in conjunction with a contact lens, which was removed at day 22 [43]. Almost 2 years after successful transplantation, a well-formed epithelium with 5 to 6 layers was present with rare PAS-positive cells, and positivity for CK3, CK19, P63, connexin 43, and MUC5AC [235]. Best corrected visual acuity significantly improved postoperatively, yet the effect was rather modest compared to CLET. Pain and photophobia were not being evaluated.

7.3. Hair Follicle Bulge-Derived Epithelial Stem Cells. Unlike OMECs, epithelial stem cells derived from the bulge region of the hair follicle are able to terminally differentiate into a corneal epithelial phenotype when transplanted onto the ocular surface [236]. The concept was proven in an animal study, in which hair follicle stem cells were cultured on a 3T3 feeder layer and transplanted into a LSCD mouse model [237]. The grafts were able to reconstruct the ocular surface in $80 \%$ of transplanted animals [237].

7.4. Amniotic Epithelial Cells. Human amniotic epithelial cells are characterized by their stem cell properties, low immunogenicity, production of growth factors that promote epithelialization, and their ability of controlled transdifferentiation into other cell types [238-241]. Amniotic epithelial cells can differentiate into corneal epithelial cells when seeded on the superficial corneal stroma in rabbit LSCD models [238-240, 242]. The differentiated cells had a similar structure, morphology, and physiology as that of normal stratified corneal epithelium. However, one study indicated that the stratified epithelial cells had no polarity with regard to defined superficial corneal epithelial cells, wing cells, or basal cells [238].

7.5. Human Embryonic Stem Cells. Human embryonic stem cells are pluripotent cells derived from the inner cell mass of the human embryo and can successfully differentiate into corneal epithelial-like cell $[243,244]$. In a study from Zhu et al., human embryonic stem cells were induced to form LESC-like cells and were seeded on an acellular porcine corneal matrix [245]. Seeded cells formed stratified and closely arranged epithelioid cell sheets consisting of a basal layer of cuboid-shaped cells (p63a and ABCG2 positive) and suprabasal layers of elongated cells (CK3 positive). In rabbit LSCD models, the tissue engineered graft had the potential to reconstruct the ocular surface [245]. Embryonic stem cells also differentiate into corneal epithelial cells when in direct contact with the corneal stroma [246]. A major drawback to the use of human embryonic stem cells is the immune response they elicit, and the ethical controversy surrounding the origin of the stem cells [244, 247].

7.6. Induced Pluripotent Stem Cells. Induced Pluripotent Stem Cells (iPSCs) are a type of stem cells generated by manipulation of differentiated adult cells. In 2006, the iPSC technique was first described by Takahashi and Yamanaka and used four specific transcription factors to dedifferentiate adult cells into PSCs [248]. Hayashi et al.described a strategy to differentiate LESCs from human iPSCs that were derived from human adult corneal limbal epithelial cells or human dermal fibroblasts [249]. The iPSCs derived from adult corneal limbal epithelial cells gave rise to more corneal epithelial colonies and exhibited higher expression of specific corneal epithelial differentiation markers than iPSCs derived from fibroblasts $[249,250]$. This may be due to the maintenance of epigenetic characteristics of the original adult cell during iPSC formation and subsequent differentiation [250, 251]. A significant drawback of the iPSC technique is that not all limbal epithelial cells preferentially differentiate into corneal epithelial cells [249]. Recently, a twostep differentiation method was developed to differentiate human iPSCs into a homogenous population of p63-positive epithelial cells with the ability to differentiate into corneal epithelial-like cells [252].

7.7. Umbilical Cord Lining Epithelial Stem Cells and Wharton's Jelly Mesenchymal Stem Cells. In 2011, Reza et al. described umbilical mucin-expressing cord lining epithelial stem cells as an alternative cell population in anterior corneal reconstruction [253]. These cells are nontumorigenic, highly proliferative, and ethically acceptable. The cells' low immunogenicity may obviate the postoperative use of immunosuppressants. In vivo verification in a rabbit model showed clear corneal surface regeneration with phenotypical CK3/CK12 expression [253]. Wharton's Jelly Mesenchymal Stem Cells have also been proposed for anterior corneal tissue engineering. Garzón et al. demonstrated that these MSCs could 
transdifferentiate in vitro into corneal epithelial-like cells, with the expression of epithelial cell markers (CK3/CK12, PKG, ZO1, and Cnx43) [254].

7.8. Mesenchymal Stem Cells. In 2006, Ma et al. were the first to expand MSCs on HAM and subsequently transplant the construct onto the ocular surface of LSCD rats [255]. Although bone marrow-derived human MSCs did not differentiate into epithelial-like cells, the transplanted MSCs successfully reconstructed the damaged corneal surface as a smooth and continuous epithelium, and avascular and transparent cornea were being observed [255]. The therapeutic effect may be due to the MSCs' anti-inflammatory and antiangiogenic properties, rather than direct epithelial differentiation. Gu et al. subsequently succeeded in differentiating rabbit-derived bone marrow MSCs into corneal epitheliallike cells [256]. In vitro, differentiation was modulated by either (i) coculturing rabbit LESCs with MSCs or (ii) adding a LESC-derived supernatant to the MSCs [256]. Several other methods of inducing MSC differentiation have since been described [257-259]. In a LSCD rat model, corneal epitheliallike differentiation was modulated by cytokines, produced by rat Corneal Stromal Cells [257]. In 2011, Reinshagen et al. injected enriched MSCs under an AMT in LSCD rabbits [258]. Data indicated that injected MSCs may maintain their stem cell character or may differentiate into epithelial progenitor cells. More recently, it has been discovered that bone marrow-derived MSCs are capable of differentiating into corneal epithelial-like cells, when cultured in specialized DMEM-medium [259]. Adipose tissue-derived MSCs and limbal MSCs also can differentiate into corneal epitheliallike cells when exposed to (i) secreted factors of differentiated human corneal epithelial cells or (ii) DMEM-medium, respectively [260-263].

7.9. Human Immature Dental Pulp Stem Cells. Human immature dental pulp stem cells express both MSC and embryonic stem cell markers and have the capacity to differentiate into derivatives of the three germinal layers in vitro. In a LSCD rabbit experiment, transplanted human immature dental pulp stem cells were capable of reconstructing the ocular surface with a well-formed corneal epithelium that expresses LESC markers in the basal cell layer and EC markers in suprabasal cell layers [74, 264].

\section{Conclusion}

Over the past few years, great advances in LESC identification and characterization and ocular surface reconstruction have been made. With the introduction of CLET and SLET, a safe and successful treatment option for LSCD has been introduced [22-60, 94-97, 119, 120]. In particular, the tendency towards (i) standardized nonxenogenic GMP protocols in scaffold manufacturing and cell cultivation and (ii) "no touch graft surgery" is expected to improve success rates in future CLET trials $[52,55,58,59]$. SLET seems to be very promising [94-97, 119, 120]; however, large cohort inclusion, allogenic transplantation, and long-term follow-up have yet to be performed. Further elaboration of "tear sampling" as a tool to identify factors that may be involved in the development and/or maintenance of corneal neovascularization in humans has been described [265]. This technique may assist in monitoring the inflammatory state of the LSCD eye and further improve preoperative management and postoperative outcome of patients. However, specific identification of the LESCs remains a hurdle and characterization is still based on a combination of phenotypic expression patterns [266]. Despite the successes and evolving techniques in LESC transplantation, detailed interaction and signaling pathways between LESCs, niche cells, and surrounding extracellular matrix are not fully understood. Research and knowledge within these domains will help understand (i) physiological LESC maintenance, (ii) in vitro and in vivo microenvironment simulation, and (iii) long-term effectiveness of LESC transplantation. Such knowledge may potentiate the development of new pharmacological solutions (e.g., eye drops that contain LESC growth factors) that stimulate remaining dormant LESCs of the diseased eye. These alternatives would be of great value in cases of extensive ocular inflammation, as these patients are not good candidates for surgical intervention.

Better in vitro and in vivo replication of the niche may also lead to more efficient cultivation and transplantation of LESCs and alternative cell populations. Of the investigated alternative seeding membranes, only HAM, fibrin, Siloxane Hydrogen contact lens, and collagen membranes have been used in patients $[22-60,94-97,119,120,149,151]$. In particular, the conditional approval of Holoclar (Chiesi, Italy) is a huge step forward in the accessibility of LSCD treatment in daily practice. Furthermore, RHC membranes seem to be very promising for tissue engineering, the collagen being of nonxenogenic origin and the addition of MPC addressing many shortcomings of conventional collagen hydrogels. Other alternative scaffolds are still in an experimental phase and have yet to be validated in humans. COMET and human conjunctival epithelial cell transplantation have both been successfully performed in selected patients [43, 221, 223$232,235]$. However, as iPSCs get widespread attention in many medical disciplines, it is believed that this autologous cell population will play a prominent role in LSCD treatment in the coming years.

In conclusion, it can be certain that better and more convenient treatment options for LSCD patients will emerge in the near future. New treatment options will target optical transparency, biocompatibility, intraoperative handling, physicochemical strength, and cost-effectiveness. The important focus on sterility, reproducibility, and minimal mutagenicity and cytotoxicity is further stimulated by the widespread introduction of GMP guidelines.

\section{Conflict of Interests}

The authors declare that there are no competing financial interests for any of them.

\section{Acknowledgments}

This research was funded by "The Research FoundationFlanders" (FWO) and EuroNanoMed2. 


\section{References}

[1] J. W. McTigue, "The human cornea: a light and electron microscopic study of the normal cornea and its alterations in various dystrophies," Transactions of the American Ophthalmological Society, vol. 65, pp. 591-660, 1967.

[2] G. Cotsarelis, S.-Z. Cheng, G. Dong, T.-T. Sun, and R. M. Lavker, "Existence of slow-cycling limbal epithelial basal cells that can be preferentially stimulated to proliferate: implications on epithelial stem cells," Cell, vol. 57, no. 2, pp. 201-209, 1989.

[3] P. A. Hall and F. M. Watt, "Stem cells: the generation and maintenance of cellular diversity," Development, vol. 106, no. 4, pp. 619-633, 1989.

[4] A. Schermer, S. Galvin, and T. T. Sun, "Differentiation-related expression of a major $64 \mathrm{~K}$ corneal keratin in vivo and in culture suggests limbal location of corneal epithelial stem cells," The Journal of Cell Biology, vol. 103, no. 1, pp. 49-62, 1986.

[5] M. S. Shapiro, J. Friend, and R. A. Thoft, "Corneal reepithelialization from the conjunctiva," Investigative Ophthalmology \& Visual Science, vol. 21, no. 1, part 1, pp. 135-142, 1981.

[6] E. J. Holland, "Epithelial transplantation for the management of severe ocular surface disease," Transactions of the American Ophthalmological Society, vol. 94, pp. 677-743, 1996.

[7] H. S. Dua and A. Azuara-Blanco, "Limbal stem cells of the corneal epithelium," Survey of Ophthalmology, vol. 44, no. 5, pp. 415-425, 2000.

[8] K. Higa, S. Shimmura, H. Miyashita, J. Shimazaki, and K. Tsubota, "Melanocytes in the corneal limbus interact with K19positive basal epithelial cells," Experimental Eye Research, vol. 81, no. 2, pp. 218-223, 2005.

[9] V. Puangsricharern and S. C. Tseng, "Cytologlogic evidence of corneal diseases with limbal stem cell deficiency," Ophthalmology, vol. 102, no. 10, pp. 1476-1485, 1995.

[10] M. Sacchetti, A. Lambiase, M. Cortes et al., "Clinical and cytological findings in limbal stem cell deficiency," Graefe's Archive for Clinical and Experimental Ophthalmology, vol. 243, no. 9, pp. 870-876, 2005.

[11] V. Barbaro, S. Ferrari, A. Fasolo et al., "Evaluation of ocular surface disorders: a new diagnostic tool based on impression cytology and confocal laser scanning microscopy," British Journal of Ophthalmology, vol. 94, no. 7, pp. 926-932, 2010.

[12] K. Jirsova, L. Dudakova, S. Kalasova, V. Vesela, and S. Merjava, "The OV-TL 12/30 clone of anti-cytokeratin 7 antibody as a new marker of corneal conjunctivalization in patients with limbal stem cell deficiency," Investigative Ophthalmology and Visual Science, vol. 52, no. 8, pp. 5892-5898, 2011.

[13] A. Ramirez-Miranda, M. N. Nakatsu, S. Zarei-Ghanavati, C. V. Nguyen, and S. X. Deng, "Keratin 13 is a more specific marker of conjunctival epithelium than keratin 19," Molecular Vision, vol. 17, pp. 1652-1661, 2011.

[14] I. Garcia, J. Etxebarria, A. Boto-De-Los-Bueis et al., "Comparative study of limbal stem cell deficiency diagnosis methods: detection of MUC5AC mRNA and goblet cells in corneal epithelium," Ophthalmology, vol. 119, no. 5, pp. 923-929, 2012.

[15] I. Jalbert, F. Stapleton, E. Papas, D. F. Sweeney, and M. Coroneo, "In vivo confocal microscopy of the human cornea," British Journal of Ophthalmology, vol. 87, no. 2, pp. 225-236, 2003.

[16] A. J. Shortt, G. A. Secker, P. M. Munro, P. T. Khaw, S. J. Tuft, and J. T. Daniels, "Characterization of the limbal epithelial stem cell niche: Novel imaging techniques permit in vivo observation and targeted biopsy of limbal epithelial stem cells," Stem Cells, vol. 25, no. 6, pp. 1402-1409, 2007.
[17] N. Efron, M. Al-Dossari, and N. Pritchard, "In vivo confocal microscopy of the bulbar conjunctiva," Clinical \& Experimental Ophthalmology, vol. 37, no. 4, pp. 335-344, 2009.

[18] J. Hong, W. Zhu, H. Zhuang et al., "In vivo confocal microscopy of conjunctival goblet cells in patients with Sjogren's syndrome dry eye," British Journal of Ophthalmology, vol. 94, no. 11, pp. 1454-1458, 2010.

[19] A. Miri, T. Alomar, M. Nubile et al., "In vivo confocal microscopic findings in patients with limbal stem cell deficiency," British Journal of Ophthalmology, vol. 96, no. 4, pp. 523-529, 2012.

[20] K. L. Lathrop, D. Gupta, L. Kagemann, J. S. Schuman, and N. SundarRaj, "Optical coherence tomography as a rapid, accurate, noncontact method of visualizing the palisades of Vogt," Investigative Opthalmology \& Visual Science, vol. 53, no. 3, pp. 1381-1387, 2012.

[21] O. Baylis, F. Figueiredo, C. Henein, M. Lako, and S. Ahmad, "13 Years of cultured limbal epithelial cell therapy: a review of the outcomes," Journal of Cellular Biochemistry, vol. 112, no. 4, pp. 993-1002, 2011.

[22] G. Pellegrini, C. E. Traverso, A. T. Franzi, M. Zingirian, R. Cancedda, and M. De Luca, "Long-term restoration of damaged corneal surfaces with autologous cultivated corneal epithelium," The Lancet, vol. 349, no. 9057, pp. 990-993, 1997.

[23] I. R. Schwab, "Cultured corneal epithelia for ocular surface disease," Transactions of the American Ophthalmological Society, vol. 97, pp. 891-986, 1999.

[24] I. R. Schwab, M. Reyes, and R. R. Isseroff, "Successful transplantation of bioengineered tissue replacements in patients with ocular surface disease," Cornea, vol. 19, no. 4, pp. 421-426, 2000.

[25] R. J. Tsai, L. M. Li, and J. K. Chen, "Reconstruction of damaged corneas by transplantation of autologous limbal epithelial cells," The New England Journal of Medicine, vol. 343, no. 2, pp. 86-93, 2000.

[26] N. Koizumi, T. Inatomi, T. Suzuki, C. Sotozono, and S. Kinoshita, "Cultivated corneal epithelial transplantation for ocular surface reconstruction in acute phase of Stevens-Johnson syndrome," Archives of Ophthalmology, vol. 119, no. 2, Article ID 11176998, pp. 298-300, 2001.

[27] N. Koizumi, T. Inatomi, T. Suzuki, C. Sotozono, and S. Kinoshita, "Cultivated corneal epithelial stem cell transplantation in ocular surface disordersllThe authors have no financial interest in this work.," Ophthalmology, vol. 108, no. 9, pp. 15691574, 2001.

[28] P. Rama, S. Bonini, A. Lambiase et al., "Autologous fibrincultured limbal stem cells permanently restore the corneal surface of patients with total limbal stem cell deficiency," Transplantation, vol. 72, no. 9, pp. 1478-1485, 2001.

[29] M. Grueterich, E. M. Espana, A. Touhami, S.-E. Ti, and S. C. G. Tseng, "Phenotypic study of a case with successful transplantation of ex vivo expanded human limbal epithelium for unilateral total limbal stem cell deficiency," Ophthalmology, vol. 109, no. 8, pp. 1547-1552, 2002.

[30] J. Shimazaki, M. Aiba, E. Goto, N. Kato, S. Shimmura, and K. Tsubota, "Transplantation of human limbal epithelium cultivated on amniotic membrane for the treatment of severe ocular surface disorders," Ophthalmology, vol. 109, no. 7, pp. 1285-1290, 2002.

[31] V. S. Sangwan, G. K. Vemuganti, G. Iftekhar, A. K. Bansal, and G. N. Rao, "Use of autologous cultured limbal and conjunctival 
epithelium in a patient with severe bilateral ocular surface disease induced by acid injury: a case report of unique application," Cornea, vol. 22, no. 5, pp. 478-481, 2003.

[32] T. Nakamura, N. Koizumi, M. Tsuzuki et al., "Successful regrafting of cultivated corneal epithelium using amniotic membrane as a carrier in severe ocular surface disease," Cornea, vol. 22, no. 1, pp. 70-71, 2003.

[33] T. Nakamura, T. Inatomi, C. Sotozono, N. Koizumi, and S. Kinoshita, "Successful primary culture and autologous transplantation of corneal limbal epithelial cells from minimal biopsy for unilateral severe ocular surface disease," Acta Ophthalmologica Scandinavica, vol. 82, no. 4, pp. 468-471, 2004.

[34] S. M. Daya, A. Watson, J. R. Sharpe et al., "Outcomes and DNA analysis of ex vivo expanded stem cell allograft for ocular surface reconstruction," Ophthalmology, vol. 112, no. 3, pp. 470477, 2005.

[35] V. S. Sangwan, H. P. Matalia, G. K. Vemuganti et al., "Early results of penetrating keratoplasty after cultivated limbal epithelium transplantation," Archives of Ophthalmology, vol. 123, no. 3, pp. 334-340, 1960.

[36] T. Nakamura, T. Inatomi, C. Sotozono et al., "Transplantation of autologous serum-derived cultivated corneal epithelial equivalents for the treatment of severe ocular surface disease," Ophthalmology, vol. 113, no. 10, pp. 1765-1772, 2006.

[37] V. S. Sangwan, H. P. Matalia, G. K. Vemuganti et al., "Clinical outcome of autologous cultivated limbal epithelium transplantation," Indian Journal of Ophthalmology, vol. 54, no. 1, pp. 2934, 2006.

[38] L. P. K. Ang, C. Sotozono, N. Koizumi, T. Suzuki, T. Inatomi, and S. Kinoshita, "A comparison between cultivated and conventional limbal stem cell transplantation for Stevens-Johnson syndrome," American Journal of Ophthalmology, vol. 143, no. 1, pp. 178-180, 2007.

[39] J. Shimazaki, K. Higa, F. Morito et al., "Factors influencing outcomes in cultivated limbal epithelial transplantation for chronic cicatricial ocular surface disorders," The American Journal of Ophthalmology, vol. 143, no. 6, pp. 945-953, 2007.

[40] M. Kawashima, T. Kawakita, Y. Satake, K. Higa, and J. Shimazaki, "Phenotypic study after cultivated limbal epithelial transplantation for limbal stem cell deficiency," Archives of Ophthalmology, vol. 125, no. 10, pp. 1337-1344, 2007.

[41] A. Fatima, G. K. Vemuganti, G. Iftekhar, G. N. Rao, and V. S. Sangwan, "In vivo survival and stratification of cultured limbal epithelium," Clinical and Experimental Ophthalmology, vol. 35, no. 1, pp. 96-98, 2007.

[42] A. J. Shortt, G. A. Secker, M. S. Rajan et al., "Ex vivo expansion and transplantation of limbal epithelial stem cells," Ophthalmology, vol. 115, no. 11, pp. 1989-1997, 2008.

[43] N. Di Girolamo, M. Bosch, K. Zamora, M. T. Coroneo, D. Wakefield, and S. L. Watson, "A contact lens-based technique for expansion and transplantation of autologous epithelial progenitors for ocular surface reconstruction," Transplantation, vol. 87, no. 10, pp. 1571-1578, 2009.

[44] D. Meller, T. Fuchsluger, M. Pauklin, and K.-P. Steuhl, “Ocular surface reconstruction in graft-versus-host disease with HLAidentical living-related allogeneic cultivated limbal epithelium after hematopoietic stem cell transplantation from the same donor," Cornea, vol. 28, no. 2, pp. 233-236, 2009.

[45] A. Baradaran-Rafii, M. Ebrahimi, M. R. Kanavi et al., "Midterm outcomes of autologous cultivated limbal stem cell transplantation with or without penetrating keratoplasty," Cornea, vol. 29, no. 5, pp. 502-509, 2010.
[46] R. A. M. C. Gisoldi, A. Pocobelli, C. M. Villani, D. Amato, and G. Pellegrini, "Evaluation of molecular markers in corneal regeneration by means of autologous cultures of limbal cells and keratoplasty," Cornea, vol. 29, no. 7, pp. 715-722, 2010.

[47] M. Thanos, M. Pauklin, K.-P. Steuhl, and D. Meller, "Ocular surface reconstruction with cultivated limbal epithelium in a patient with unilateral stem cell deficiency caused by epidermolysis bullosa dystrophica hallopeau-siemens," Cornea, vol. 29, no. 4, pp. 462-464, 2010.

[48] E. Di Iorio, S. Ferrari, A. Fasolo, E. Böhm, D. Ponzin, and V. Barbaro, "Techniques for culture and assessment of limbal stem cell grafts," Ocular Surface, vol. 8, no. 3, pp. 146-153, 2010.

[49] P. Rama, S. Matuska, G. Paganoni, A. Spinelli, M. De Luca, and G. Pellegrini, "Limbal stem-cell therapy and long-term corneal regeneration," The New England Journal of Medicine, vol. 363, no. 2, pp. 147-155, 2010.

[50] S. A. I. Kolli, S. Ahmad, M. Lako, and F. Figueiredo, "Successful clinical implementation of corneal epithelial stem cell therapy for treatment of unilateral limbal stem cell deficiency," Stem Cells, vol. 28, no. 3, pp. 597-610, 2010.

[51] M. Pauklin, T. A. Fuchsluger, H. Westekemper, K.-P. Steuhl, and D. Meller, "Midterm results of cultivated autologous and allogeneic limbal epithelial transplantation in limbal stem cell deficiency," Developments in Ophthalmology, vol. 45, pp. 57-70, 2010.

[52] V. S. Sangwan, S. Basu, G. K. Vemuganti et al., "Clinical outcomes of xeno-free autologous cultivated limbal epithelial transplantation: a 10-year study," British Journal of Ophthalmology, vol. 95, no. 11, pp. 1525-1529, 2011.

[53] S. Sharma, R. Tandon, S. Mohanty et al., "Culture of corneal limbal epithelial stem cells: experience from benchtop to bedside in a tertiary care hospital in India," Cornea, vol. 30, no. 11, pp. 1223-1232, 2011.

[54] P. Prabhasawat, P. Ekpo, M. Uiprasertkul, S. Chotikavanich, and N. Tesavibul, "Efficacy of cultivated corneal epithelial stem cells for ocular surface reconstruction," Clinical Ophthalmology, vol. 6, pp. 1483-1492, 2012.

[55] S. Basu, H. Ali, and V. S. Sangwan, "Clinical outcomes of repeat autologous cultivated limbal epithelial transplantation for ocular surface burns," The American Journal of Ophthalmology, vol. 153, no. 4, pp. 643-650.e2, 2012.

[56] S. Subramaniam, K. Sejpal, A. Fatima, S. Gaddipati, G. Vemuganti, and V. Sangwan, "Coculture of autologous limbal and conjunctival epithelial cells to treat severe ocular surface disorders: Long-term survival analysis," Indian Journal of Ophthalmology, vol. 61, no. 5, pp. 202-207, 2013.

[57] K. Sejpal, M. H. Ali, S. Maddileti et al., "Cultivated limbal epithelial transplantation in children with ocular surface burns," JAMA Ophthalmology, vol. 131, no. 6, pp. 731-736, 2013.

[58] M. Pathak, S. Cholidis, K. Haug et al., "Clinical transplantation of ex vivo expanded autologous limbal epithelial cells using a culture medium with human serum as single supplement: a retrospective case series," Acta Ophthalmologica, vol. 91, no. 8, pp. 769-775, 2013.

[59] N. Zakaria, T. Possemiers, S. Dhubhghaill et al., "Results of a phase I/II clinical trial: standardized, non-xenogenic, cultivated limbal stem cell transplantation," Journal of Translational Medicine, vol. 12, article 58, 2014.

[60] J. Vazirani, S. Basu, H. Kenia et al., "Unilateral partial limbal stem cell deficiency: contralateral versus ipsilateral autologous cultivated limbal epithelial transplantation," American Journal of Ophthalmology, vol. 157, no. 3, pp. 584.e2-590.e2, 2014. 
[61] K. Y. H. Chee, A. Kicic, and S. J. Wiffen, "Limbal stem cells: the search for a marker," Clinical \& Experimental Ophthalmology, vol. 34, no. 1, pp. 64-73, 2006.

[62] M. A. Dziasko, H. E. Armer, H. J. Levis, A. J. Shortt, S. Tuft, and J. T. Daniels, "Localisation of epithelial cells capable of holoclone formation in vitro and direct interaction with stromal cells in the native human limbal crypt," PLoS ONE, vol. 9, no. 4, Article ID e94283, 2014.

[63] I. K. Gipson, "The epithelial basement membrane zone of the limbus," Eye, vol. 3, part 2, pp. 132-140, 1989.

[64] J. T. Daniels, J. K. G. Dart, S. J. Tuft, and P. T. Khaw, "Corneal stem cells in review," Wound Repair and Regeneration, vol. 9, no. 6, pp. 483-494, 2001.

[65] F. E. Kruse and S. C. Tseng, "Growth factors modulate clonal growth and differentiation of cultured rabbit limbal and corneal epithelium," Investigative Ophthalmology \& Visual Science, vol. 34, no. 6, pp. 1963-1976, 1993.

[66] R. Schofield, "The stem cell system," Biomedicine \& Pharmacotherapy, vol. 37, no. 8, pp. 375-380, 1983.

[67] S. C. Tseng, "Concept and application of limbal stem cells," Eye, vol. 3, part 2, pp. 141-157, 1989.

[68] F. E. Kruse, "Stem cells and corneal epithelial regeneration," Eye, vol. 8, part 2, pp. 170-183, 1994.

[69] H. S. Dua, J. S. Saini, A. Azuara-Blanco, and P. Gupta, "Limbal stem cell deficiency: concept, aetiology, clinical presentation, diagnosis and management," Indian Journal of Ophthalmology, vol. 48 , no. 2 , pp. 83-92, 2000.

[70] R. A. Thoft and J. Friend, "The X, Y, Z hypothesis of corneal epithelial maintenance," Investigative Ophthalmology \& Visual Science, vol. 24, no. 10, pp. 1442-1443, 1983.

[71] K. Nishida, S. Kinoshita, Y. Ohashi, Y. Kuwayama, and S. Yamamoto, "Ocular surface abnormalities in aniridia," American Journal of Ophthalmology, vol. 120, no. 3, pp. 368-375, 1995.

[72] K. Ramaesh, T. Ramaesh, G. N. Dutton, and B. Dhillon, "Evolving concepts on the pathogenic mechanisms of aniridia related keratopathy," The International Journal of Biochemistry \& Cell Biology, vol. 37, no. 3, pp. 547-557, 2005.

[73] A. F. Felipe, A. Abazari, K. M. Hammersmith, C. J. Rapuano, P. K. Nagra, and B. M. Peiro, "Corneal changes in ectrodactylyectodermal dysplasia-cleft lip and palate syndrome: case series and literature review," International Ophthalmology, vol. 32, no. 5, pp. 475-480, 2012.

[74] J. Á. Gomes, B. Geraldes Monteiro, G. B. Melo et al., "Corneal reconstruction with tissue-engineered cell sheets composed of human immature dental pulp stem cells," Investigative Opthalmology \& Visual Science, vol. 51, no. 3, pp. 1408-1414, 2010.

[75] D. Aslan and R. F. Akata, "Dyskeratosis congenita and limbal stem cell deficiency," Experimental Eye Research, vol. 90, no. 3, pp. 472-473, 2010.

[76] D. Aslan, R. F. Akata, H. Holme, T. Vulliamy, and I. Dokal, "Limbal stem cell deficiency in patients with inherited stem cell disorder of dyskeratosis congenita," International Ophthalmology, vol. 32, no. 6, pp. 615-622, 2012.

[77] W. J. Hughes, "Alkali burns of the eye," Clinical and Pathologic Course, vol. 36, article 189, 1946.

[78] R. P. Bhatia, R. Srivastava, and A. Ghosh, "Limbal stem cell study in contact lens wearers," Annals of Ophthalmology, vol. 41, no. 2, pp. 87-92, 2009.

[79] S. Ahmad, "Concise review: limbal stem cell deficiency, dysfunction, and distress," Stem Cells Translational Medicine, vol. 1, no. 2, pp. 110-115, 2012.
[80] S. Deng, K. Sejpal, and P. Bakhtiari, "Presentation, diagnosis and management of limbal stem cell deficiency," Middle East African Journal of Ophthalmology, vol. 20, no. 1, pp. 5-10, 2013.

[81] M. S. Sridhar, G. K. Vemuganti, A. K. Bansal, and G. N. Rao, "Impression cytology-proven corneal stem cell deficiency in patients after surgeries involving the limbus," Cornea, vol. 20, no. 2, pp. 145-148, 2001.

[82] F. dos Santos Paris, E. D. Gonçalves, J. de Nadai Barros, M. S. de Queiroz Campos, E. H. Sato, and J. A. P. Gomes, "Impression cytology findings in bullous keratopathy," British Journal of Ophthalmology, vol. 94, no. 6, pp. 773-776, 2010.

[83] R. T. F. Pires, A. Chokshi, and S. C. G. Tseng, "Amniotic membrane transplantation or conjunctival limbal autograft for limbal stem cell deficiency induced by 5 -fluorouracil in glaucoma surgeries," Cornea, vol. 19, no. 3, pp. 284-287, 2000.

[84] B. W. Dudney and M. A. Malecha, "Limbal stem cell deficiency following topical mitomycin $\mathrm{C}$ treatment of conjunctivalcorneal intraepithelial neoplasia," American Journal of Ophthalmology, vol. 137, no. 5, pp. 950-951, 2004.

[85] P. Ellies, D. F. Anderson, A. Touhami, and S. C. G. Tseng, "Limbal stem cell deficiency arising from systemic chemotherapy," British Journal of Ophthalmology, vol. 85, no. 3, pp. 373-374, 2001.

[86] G. Geerling, J. T. Daniels, J. K. G. Dart, I. A. Cree, and P. T. Khaw, "Toxicity of natural tear substitutes in a fully defined culture model of human corneal epithelial cells," Investigative Ophthalmology and Visual Science, vol. 42, no. 5, pp. 948-956, 2001.

[87] F. Mantelli and P. Argüeso, "Functions of ocular surface mucins in health and disease," Current Opinion in Allergy and Clinical Immunology, vol. 8, no. 5, pp. 477-483, 2008.

[88] S. Rauz and V. P. Saw, "Serum eye drops, amniotic membrane and limbal epithelial stem cells_-tools in the treatment of ocular surface disease," Cell and Tissue Banking, vol. 11, no. 1, pp. 13-27, 2010.

[89] M. Fernandes, V. S. Sangwan, S. K. Rao et al., "Limbal stem cell transplantation," Indian Journal of Ophthalmology, vol. 52, no. 1, Article ID 15132374, pp. 5-22, 2004.

[90] M. M. Schornack, "Limbal stem cell disease: management with scleral lenses," Clinical and Experimental Optometry, vol. 94, no. 6, pp. 592-594, 2011.

[91] H. S. Dua, "The conjunctiva in corneal epithelial wound healing," British Journal of Ophthalmology, vol. 82, no. 12, pp. 1407-1411, 1998.

[92] D. F. Anderson, P. Ellies, R. T. F. Pires, and S. C. G. Tseng, "Amniotic membrane transplantation for partial limbal stem cell deficiency," British Journal of Ophthalmology, vol. 85, no. 5, pp. 567-575, 2001.

[93] A. J. Shortt, G. A. Secker, M. D. Notara et al., "Transplantation of ex vivo cultured limbal epithelial stem cells: a review of techniques and clinical results," Survey of Ophthalmology, vol. 52, no. 5, pp. 483-502, 2007.

[94] V. S. Sangwan, S. Basu, S. MacNeil, and D. Balasubramanian, "Simple limbal epithelial transplantation (SLET): a novel surgical technique for the treatment of unilateral limbal stem cell deficiency," British Journal of Ophthalmology, vol. 96, no. 7, pp. 931-934, 2012.

[95] G. Amescua, M. Atallah, N. Nikpoor, A. Galor, and V. L. Perez, "Modified simple limbal epithelial transplantation using cryopreserved amniotic membrane for unilateral limbal stem cell deficiency," American Journal of Ophthalmology, vol. 158, no. 3, pp. 469.e2-475.e2, 2014. 
[96] S. Bhalekar, S. Basu, and V. S. Sangwan, "Successful management of immunological rejection following allogeneic simple limbal epithelial transplantation (SLET) for bilateral ocular burns," BMJ Case Reports, vol. 2013, 2013.

[97] J. Vazirani, S. Basu, and V. Sangwan, "Successful simple limbal epithelial transplantation (SLET) in lime injury-induced limbal stem cell deficiency with ocular surface granuloma," BMJ Case Reports, 2013.

[98] R. K. Molvaer, A. Andreasen, S. Heegaard et al., "Interactive 3D computer model of the human corneolimbal region: crypts, projections and stem cells," Acta Ophthalmologica, vol. 91, no. 5, pp. 457-462, 2013.

[99] H. S. Dua, V. A. Shanmuganathan, A. O. Powell-Richards, P. J. Tighe, and A. Joseph, "Limbal epithelial crypts: a novel anatomical structure and a putative limbal stem cell niche," British Journal of Ophthalmology, vol. 89, no. 5, pp. 529-532, 2005.

[100] C. Bath, D. Muttuvelu, J. Emmersen, H. Vorum, J. Hjortdal, and V. Zachar, "Correction: transcriptional dissection of human limbal niche compartments by massive parallel sequencing," PLoS ONE, vol. 8, no. 11, 2013.

[101] A. Joseph, A. O. R. Powell-Richards, V. A. Shanmuganathan, and H. S. Dua, "Epithelial cell characteristics of cultured human limbal explants," British Journal of Ophthalmology, vol. 88, no. 3, pp. 393-398, 2004.

[102] U. Schlötzer-Schrehardt and F. E. Kruse, "Identification and characterization of limbal stem cells," Experimental Eye Research, vol. 81, no. 3, pp. 247-264, 2005.

[103] K. Watanabe, K. Nishida, M. Yamato et al., "Human limbal epithelium contains side population cells expressing the ATPbinding cassette transporter ABCG2," FEBS Letters, vol. 565, no. 1-3, pp. 6-10, 2004.

[104] A. Yang, R. Schweitzer, D. Sun et al., "p63 is essential for regenerative proliferation in limb, craniofacial and epithelial development," Nature, vol. 398, no. 6729, pp. 714-718, 1999.

[105] E. Di Iorio, V. Barbaro, A. Ruzza, D. Ponzin, G. Pellegrini, and M. De Luca, "Isoforms of $\Delta \mathrm{Np} 63$ and the migration of ocular limbal cells in human corneal regeneration," Proceedings of the National Academy of Sciences of the United States of America, vol. 102, no. 27, pp. 9523-9528, 2005.

[106] P. Ordonez, S. Chow, D. Wakefield, and N. Di Girolamo, "Human limbal epithelial progenitor cells express $\alpha \mathrm{v} \beta 5$ integrin and the interferon-inducible chemokine CXCL10/IP10," Stem Cell Research, vol. 11, no. 2, pp. 888-901, 2013.

[107] B. R. Ksander, P. E. Kolovou, B. J. Wilson et al., “ $A B C B 5$ is a limbal stem cell gene required for corneal development and repair," Nature, vol. 511, no. 7509, pp. 353-357, 2014.

[108] M. De Luca, G. Pellegrini, and H. Green, "Regeneration of squamous epithelia from stem cells of cultured grafts," Regenerative Medicine, vol. 1, no. 1, pp. 45-57, 2006.

[109] H. Green, “The birth of therapy with cultured cells," BioEssays, vol. 30, no. 9, pp. 897-903, 2008.

[110] Y. Oie, R. Hayashi, R. Takagi et al., "A novel method of culturing human oral mucosal epithelial cell sheet using postmitotic human dermal fibroblast feeder cells and modified keratinocyte culture medium for ocular surface reconstruction," British Journal of Ophthalmology, vol. 94, no. 9, pp. 1244-1250, 2010.

[111] M. Omoto, H. Miyashita, S. Shimmura et al., "The use of human mesenchymal stem cell-derived feeder cells for the cultivation of transplantable epithelial sheets," Investigative Opthalmology \& Visual Science, vol. 50, no. 5, pp. 2109-2115, 2009.
[112] S. M. Sharma, T. Fuchsluger, S. Ahmad et al., "Comparative analysis of human-derived feeder layers with $3 \mathrm{~T} 3$ fibroblasts for the ex vivo expansion of human limbal and oral epithelium," Stem Cell Reviews and Reports, vol. 8, no. 3, pp. 696-705, 2012.

[113] P. Carrier, A. Deschambeault, C. Audet et al., "Impact of cell source on human cornea reconstructed by tissue engineering," Investigative Opthalmology \& Visual Science, vol. 50, no. 6, pp. 2645-2652, 2009.

[114] M. N. Nakatsu, S. Gonzalez, H. Mei, and S. X. Deng, "uman limbal mesenchymal cells support the growth of human corneal epithelial stem/progenitor cells," Investigative Ophthalmology \& Visual Science, vol. 55, no. 10, pp. 6953-6959, 2014.

[115] The Commission of the European Communities, "Commission directive 2003/94/EC of 8 October 2003. Laying down the principles and guidelines of good manufacturing practice in respect of medicinal products for human use and investigational medicinal products for human use," Official Journal of the European Union, vol. L262, pp. 22-26, 2003.

[116] M. Notara, D. B. Haddow, S. MacNeil, and J. T. Daniels, "A xenobiotic-free culture system for human limbal epithelial stem cells," Regenerative Medicine, vol. 2, no. 6, pp. 919-927, 2007.

[117] V. M. Varghese, T. Prasad, and T. V. Kumary, "Optimization of culture conditions for an efficient xeno-feeder free limbal cell culture system towards ocular surface regeneration," Microscopy Research and Technique, vol. 73, no. 11, pp. 1045-1052, 2010.

[118] N. Zakaria, C. Koppen, V. Van Tendeloo, Z. Berneman, A. Hopkinson, and M.-J. Tassignon, "Standardized limbal epithelial stem cell graft generation and transplantation," Tissue Engineering Part C: Methods, vol. 16, no. 5, pp. 921-927, 2010.

[119] S. Bhalekar, S. Basu, I. Lal, and V. S. Sangwan, "Successful autologous simple limbal epithelial transplantation (SLET) in previously failed paediatric limbal transplantation for ocular surface burns," BMJ Case Reports, 2013.

[120] S. Bhalekar, V. S. Sangwan, and S. Basu, "Growth of corneal epithelial cells over in situ therapeutic contact lens after simple limbal epithelial transplantation (SLET)," BMJ Case Reports, 2013.

[121] S. Ijiri, A. Kobayashi, K. Sugiyama, and S. C. G. Tseng, "Evaluation of visual acuity and color vision in normal human eyes with a sutureless temporary amniotic membrane patch," American Journal of Ophthalmology, vol. 144, no. 6, pp. 938.el942.e1, 2007.

[122] D. H.-K. Ma, J.-Y. Lai, H.-Y. Cheng, C.-C. Tsai, and L.K. Yeh, "Carbodiimide cross-linked amniotic membranes for cultivation of limbal epithelial cells," Biomaterials, vol. 31, no. 25, pp. 6647-6658, 2010.

[123] J.-Y. Lai and D. H.-K. Ma, "Glutaraldehyde cross-linking of amniotic membranes affects their nanofibrous structures and limbal epithelial cell culture characteristics," International Journal of Nanomedicine, vol. 8, no. 1, pp. 4157-4168, 2013.

[124] J.-Y. Lai, S. J. Lue, H.-Y. Cheng, and D. H. Ma, "Effect of matrix nanostructure on the functionality of carbodiimide crosslinked amniotic membranes as limbal epithelial cell scaffolds," Journal of Biomedical Nanotechnology, vol. 9, no. 12, pp. 20482062, 2013.

[125] S. Sekar, K. Sasirekha, S. Krishnakumar, and T. P. Sastry, "A novel cross-linked human amniotic membrane for corneal implantations," Proceedings of the Institution of Mechanical Engineers Part H: Journal of Engineering in Medicine, vol. 227, no. 3, pp. 221-228, 2013.

[126] J.-Y. Lai, P.-R. Wang, L.-J. Luo, and S.-T. Chen, "Stabilization of collagen nanofibers with l-lysine improves the ability of 
carbodiimide cross-linked amniotic membranes to preserve limbal epithelial progenitor cells," International Journal of Nanomedicine, vol. 9, no. 1, pp. 5117-5130, 2014.

[127] H. S. Geggel, J. Friend, and R. A. Thoft, "Collagen gel for ocular surface," Investigative Ophthalmology \& Visual Science, vol. 26, no. 6, pp. 901-905, 1985.

[128] M. Griffith, W. B. Jackson, N. Lagali, K. Merrett, F. Li, and P. Fagerholm, "Artificial corneas: a regenerative medicine approach," Eye, vol. 23, no. 10, pp. 1985-1989, 2009.

[129] E. J. Orwin and A. Hubel, "In vitro culture characteristics of corneal epithelial, endothelial, and keratocyte cells in a native collagen matrix," Tissue Engineering, vol. 6, no. 4, pp. 307-319, 2000.

[130] W. M. Ambrose, A. Salahuddin, S. So et al., "Collagen Vitrigel membranes for the in vitro reconstruction of separate corneal epithelial, stromal, and endothelial cell layers," Journal of Biomedical Materials Research Part B: Applied Biomaterials, vol. 90, no. 2, pp. 818-831, 2009.

[131] Y. G. He and J. P. McCulley, "Growing human corneal epithelium on collagen shield and subsequent transfer to denuded cornea in vitro," Current Eye Research, vol. 10, no. 9, pp. 851-863, 1991.

[132] H. Kobayashi and Y. Ikada, "Covalent immobilization of proteins on to the surface of poly(vinyl alcohol) hydrogel," Biomaterials, vol. 12, no. 8, pp. 747-751, 1991.

[133] K. Merrett, C. M. Griffith, Y. Deslandes, G. Pleizier, and H. Sheardown, "Adhesion of corneal epithelial cells to cell adhesion peptide modified pHEMA surfaces," Journal of Biomaterials Science, Polymer Edition, vol. 12, no. 6, pp. 647-671, 2001.

[134] L. Aucoin, C. M. Griffith, G. Pleizier, Y. Deslandes, and H. Sheardown, "Interactions of corneal epithelial cells and surfaces modified with cell adhesion peptide combinations," Journal of Biomaterials Science, Polymer Edition, vol. 13, no. 4, pp. 447-462, 2002.

[135] C. Wallace, J. T. Jacob, A. Stoltz, J. Bi, and K. Bundy, "Corneal epithelial adhesion strength to tethered-protein/peptide modified hydrogel surfaces," Journal of Biomedical Materials Research, vol. 72, no. 1, pp. 19-24, 2005.

[136] N. Ahmadiankia, M. Ebrahimi, A. Hosseini, and H. Baharvand, "Effects of different extracellular matrices and co-cultures on human limbal stem cell expansion in vitro," Cell Biology International, vol. 33, no. 9, pp. 978-987, 2009.

[137] A. Chakraborty, J. Dutta, S. Das, and H. Datta, "Comparison of ex vivo cultivated human limbal epithelial stem cell viability and proliferation on different substrates," International Ophthalmology, vol. 33, no. 6, pp. 665-670, 2013.

[138] Y. Liu, M. Griffith, M. A. Watsky et al., "Properties of porcine and recombinant human collagen matrices for optically clear tissue engineering applications," Biomacromolecules, vol. 7, no. 6, pp. 1819-1828, 2006.

[139] M. Rafat, F. Li, P. Fagerholm et al., "PEG-stabilized carbodiimide crosslinked collagen-chitosan hydrogels for corneal tissue engineering," Biomaterials, vol. 29, no. 29, pp. 3960-3972, 2008.

[140] N. Pasyechnikova, V. Vit, M. Leus et al., "Collagen-based bioengineered substitutes of donor corneal allograft implantation: assessment and hypotheses," Medical Hypothesis, Discovery \& Innovation Ophthalmology Journal, vol. 1, no. 1, pp. 10-13, 2012.

[141] C. C. Lin, R. Ritch, S. M. Lin et al., "A new fish scale-derived scaffold for corneal regeneration," European Cells \& Materials, vol. 19, pp. 50-57, 2010.
[142] S. Krishnan, S. Sekar, M. F. Katheem, S. Krishnakumar, and T. P. Sastry, "Fish scale collagen-a novel material for corneal tissue engineering," Artificial Organs, vol. 36, no. 9, pp. 829-835, 2012.

[143] T. H. Van Essen, C. C. Lin, A. K. Hussain et al., "A fish scalederived collagen matrix as artificial cornea in rats: properties and potential," Investigative Opthalmology \& Visual Science, vol. 54, no. 5, pp. 3224-3233, 2013.

[144] Z. Wu, Q. Zhou, H. Duan et al., "Reconstruction of auto-tissueengineered lamellar cornea by dynamic culture for transplantation: a rabbit model," PLoS ONE, vol. 9, no. 4, Article ID e93012, 2014.

[145] J. Myllyharju, M. Nokelainen, A. Vuorela, and K. I. Kivirikko, "Expression of recombinant human type I-III collagens in the yeast Pichia pastoris," Biochemical Society Transactions, vol. 28, no. 4, pp. 353-357, 2000.

[146] D. Olsen, C. Yang, M. Bodo et al., "Recombinant collagen and gelatin for drug delivery," Advanced Drug Delivery Reviews, vol. 55, no. 12, pp. 1547-1567, 2003.

[147] M. Tomita, H. Munetsuna, T. Sato et al., "Transgenic silkworms produce recombinant human type III procollagen in cocoons," Nature Biotechnology, vol. 21, no. 1, pp. 52-56, 2002.

[148] H. Stein, M. Wilensky, Y. Tsafrir et al., "Production of bioactive, post-translationally modified, heterotrimeric, human recombinant type-I collagen in transgenic tobacco," Biomacromolecules, vol. 10, no. 9, pp. 2640-2645, 2009.

[149] P. Fagerholm, N. S. Lagali, J. A. Ong et al., "Stable corneal regeneration four years after implantation of a cell-free recombinant human collagen scaffold," Biomaterials, vol. 35, no. 8, pp. 2420 2427, 2014.

[150] M. Mirazul Islam, V. Cèpla, C. He et al., "Functional fabrication of recombinant human collagen-phosphorylcholine hydrogels for regenerative medicine applications," Acta Biomaterialia, vol. 12, pp. 70-80, 2015.

[151] O. Buznyk, N. Pasyechnikova, M. M. Islam, S. Iakymenko, P. Fagerholm, and M. Griffith, "Bioengineered corneas grafted as alternatives to human donor corneas in three high-risk patients," Clinical and Translational Science, 2015.

[152] E. Bell, B. Ivarsson, and C. Merrill, "Production of a tissue-like structure by contraction of collagen lattices by human fibroblasts of different proliferative potential in vitro," Proceedings of the National Academy of Sciences of the United States of America, vol. 76, no. 3, pp. 1274-1278, 1979.

[153] N. Lagali, M. Griffith, P. Fagerholm, K. Merrett, M. Huynh, and R. Munger, "Innervation of tissue-engineered recombinant human collagen-based corneal substitutes: a comparative in vivo confocal microscopy study," Investigative Ophthalmology and Visual Science, vol. 49, no. 9, pp. 3895-3902, 2008.

[154] K. Merrett, P. Fagerholm, C. R. McLaughlin et al., "Tissueengineered recombinant human collagen-based corneal substitutes for implantation: performance of type I versus type III collagen," Investigative Opthalmology \& Visual Science, vol. 49, no. 9, pp. 3887-3894, 2008.

[155] W. Liu, K. Merrett, M. Griffith et al., "Recombinant human collagen for tissue engineered corneal substitutes," Biomaterials, vol. 29, no. 9, pp. 1147-1158, 2008.

[156] W. Liu, C. Deng, C. R. McLaughlin et al., "Collagenphosphorylcholine interpenetrating network hydrogels as corneal substitutes," Biomaterials, vol. 30, no. 8, pp. 1551-1559, 2009. 
[157] C. R. McLaughlin, M. C. Acosta, C. Luna et al., "Regeneration of functional nerves within full thickness collagenphosphorylcholine corneal substitute implants in guinea pigs," Biomaterials, vol. 31, no. 10, pp. 2770-2778, 2010.

[158] M. Griffith, M. Islam, S. Iakymenko, N. Pasyechnikova, and O. Buznyk, "Next generation corneal implants as alternative to high risk donor transplantation," Acta Ophthalmologica, vol. 92, supplement s253, 2014.

[159] M. Grolik, K. Szczubiałka, B. Wowra et al., "Hydrogel membranes based on genipin-cross-linked chitosan blends for corneal epithelium tissue engineering," Journal of Materials Science: Materials in Medicine, vol. 23, no. 8, pp. 1991-2000, 2012.

[160] S. Mi, B. Chen, B. Wright, and C. J. Connon, "Plastic compression of a collagen gel forms a much improved scaffold for ocular surface tissue engineering over conventional collagen gels," Journal of Biomedical Materials Research Part A, vol. 95, no. 2, pp. 447-453, 2010.

[161] H. J. Levis, R. A. Brown, and J. T. Daniels, "Plastic compressed collagen as a biomimetic substrate for human limbal epithelial cell culture," Biomaterials, vol. 31, no. 30, pp. 7726-7737, 2010.

[162] H. J. Levis, G. S. L. Peh, K.-P. Toh et al., "Plastic compressed collagen as a novel carrier for expanded human corneal endothelial cells for transplantation," PLoS ONE, vol. 7, no. 11, Article ID e50993, 2012.

[163] H. J. Levis, J. Menzel-Severing, R. A. Drake, and J. T. Daniels, "Plastic compressed collagen constructs for ocular cell culture and transplantation: a new and improved technique of confined fluid loss," Current Eye Research, vol. 38, no. 1, pp. 41-52, 2013.

[164] S. Mi, V. V. Khutoryanskiy, R. R. Jones, X. Zhu, I. W. Hamley, and C. J. Connon, "Photochemical cross-linking of plastically compressed collagen gel produces an optimal scaffold for corneal tissue engineering," Journal of Biomedical Materials Research Part A, vol. 99, no. 1, pp. 1-8, 2011.

[165] H. I. Atrah, "Fibrin glue," The British Medical Journal, vol. 308, no. 6934, pp. 933-934, 1994.

[166] M. Radosevich, H. A. Goubran, and T. Burnouf, "Fibrin sealant: scientific rationale, production methods, properties, and current clinical use," Vox Sanguinis, vol. 72, no. 3, pp. 133-143, 1997.

[167] K. H. Siedentop, J. J. Park, A. N. Shah, T. K. Bhattacharyya, and K. M. O'Grady, "Safety and efficacy of currently available fibrin tissue adhesives," American Journal of Otolaryngology, vol. 22, no. 4, pp. 230-235, 2001.

[168] C. Buchta, M. Dettke, P. T. Funovics et al., "Impact of manufacturing, irradiation and filtration steps to bacterial contamination of autologous fibrin sealant," Biologicals, vol. 32, no. 3, pp. 165-169, 2004.

[169] M. Talbot, P. Carrier, C. J. Giasson et al., "Autologous transplantation of rabbit limbal epithelia cultured on fibrin gels for ocular surface reconstruction," Molecular Vision, vol. 12, pp. 6575, 2006.

[170] L. Lu, P. S. Reinach, and W. W. Kao, "Corneal epithelial wound healing," Experimental Biology and Medicine, vol. 226, no. 7, pp. 653-664, 2001.

[171] N. Di Girolamo, J. Chui, D. Wakefield, and M. T. Coroneo, "Cultured human ocular surface epithelium on therapeutic contact lenses," British Journal of Ophthalmology, vol. 91, no. 4, pp. 459-464, 2007.

[172] A. Gore, V. Horwitz, H. Gutman et al., "Cultivation and characterization of limbal epithelial stem cells on contact lenses with a feeder layer: toward the treatment of limbal stem cell deficiency," Cornea, vol. 33, no. 1, pp. 65-71, 2014.
[173] K. D. Brown, S. Low, I. Mariappan et al., "Plasma polymercoated contact lenses for the culture and transfer of corneal epithelial cells in the treatment of limbal stem cell deficiency," Tissue Engineering Part A, vol. 20, no. 3-4, pp. 646-655, 2014.

[174] S. Sharma, D. Gupta, S. Mohanty, M. Jassal, A. K. Agrawal, and R. Tandon, "Surface-modified electrospun poly(epsiloncaprolactone) scaffold with improved optical transparency and bioactivity for damaged ocular surface reconstruction," Investigative Ophthalmology \& Visual Science, vol. 55, no. 2, pp. 899907, 2014.

[175] J. Berger, M. Reist, J. M. Mayer, O. Felt, N. A. Peppas, and R. Gurny, "Structure and interactions in covalently and ionically crosslinked chitosan hydrogels for biomedical applications," European Journal of Pharmaceutics and Biopharmaceutics, vol. 57, no. 1, pp. 19-34, 2004.

[176] E. Khor and L. Y. Lim, "Implantable applications of chitin and chitosan," Biomaterials, vol. 24, no. 13, pp. 2339-2349, 2003.

[177] S. Bhat, A. Tripathi, and A. Kumar, "Supermacroprous chitosanagarose-gelatin cryogels: in vitro characterization and in vivo assessment for cartilage tissue engineering," Journal of The Royal Society Interface, vol. 8, no. 57, pp. 540-554, 2011.

[178] H. Liu, J. Mao, K. Yao, G. Yang, L. Cui, and Y. Cao, "A study on a chitosan-gelatin-hyaluronic acid scaffold as artificial skin in vitro and its tissue engineering applications," Journal of Biomaterials Science, Polymer Edition, vol. 15, no. 1, pp. 25-40, 2004.

[179] A. De la Mata, T. Nieto-Miguel, M. López-Paniagua et al., "Chitosan-gelatin biopolymers as carrier substrata for limbal epithelial stem cells," Journal of Materials Science: Materials in Medicine, vol. 24, no. 12, pp. 2819-2829, 2013.

[180] K.-H. Kim, L. Jeong, H.-N. Park et al., "Biological efficacy of silk fibroin nanofiber membranes for guided bone regeneration," Journal of Biotechnology, vol. 120, no. 3, pp. 327-339, 2005.

[181] C. Shangkai, T. Naohide, Y. Koji et al., "Transplantation of allogeneic chondrocytes cultured in fibroin sponge and stirring chamber to promote cartilage regeneration," Tissue Engineering, vol. 13, no. 3, pp. 483-492, 2007.

[182] K. H. Lee, D. H. Baek, C. S. Ki, and Y. H. Park, "Preparation and characterization of wet spun silk fibroin/poly(vinyl alcohol) blend filaments," International Journal of Biological Macromolecules, vol. 41, no. 2, pp. 168-172, 2007.

[183] K. Higa, N. Takeshima, F. Moro et al., "Porous silk fibroin film as a transparent carrier for cultivated corneal epithelial sheets," Journal of Biomaterials Science, Polymer Edition, vol. 22, no. 17, pp. 2261-2276, 2011.

[184] L. J. Bray, K. A. George, S. L. Ainscough, D. W. Hutmacher, T. V. Chirila, and D. G. Harkin, "Human corneal epithelial equivalents constructed on Bombyx mori silk fibroin membranes," Biomaterials, vol. 32, no. 22, pp. 5086-5091, 2011.

[185] J. Liu, B. D. Lawrence, A. Liu, I. R. Schwab, L. A. Oliveira, and M. I. Rosenblatt, "Silk fibroin as a biomaterial substrate for corneal epithelial cell sheet generation," Investigative Opthalmology \& Visual Science, vol. 53, no. 7, pp. 4130-4130, 2012.

[186] L. J. Bray, K. A. George, D. W. Hutmacher, T. V. Chirila, and D. G. Harkin, "A dual-layer silk fibroin scaffold for reconstructing the human corneal limbus," Biomaterials, vol. 33, no. 13, pp. 35293538, 2012.

[187] T. A. Hogerheyde, S. Suzuki, S. A. Stephenson et al., "Assessment of freestanding membranes prepared from Antheraea pernyi silk fibroin as a potential vehicle for corneal epithelial cell transplantation," Biomedical Materials, vol. 9, no. 2, Article ID 025016, 2014. 
[188] L. Guan, P. Tian, H. Ge et al., "Chitosan-functionalized silk fibroin 3D scaffold for keratocyte culture," Journal of Molecular Histology, vol. 44, no. 5, pp. 609-618, 2013.

[189] L. Guan, H. Ge, X. Tang et al., "Use of a silk fibroin-chitosan scaffold to construct a tissue-engineered corneal stroma," Cells Tissues Organs, vol. 198, no. 3, pp. 190-197, 2013.

[190] B. P. Danysh, K. J. Czymmek, P. T. Olurin, J. G. Sivak, and M. K. Duncan, "Contributions of mouse genetic background and age on anterior lens capsule thickness," The Anatomical Record, vol. 291, no. 12, pp. 1619-1627, 2008.

[191] S. Krag, T. Olsen, and T. T. Andreassen, "Biomechanical characteristics of the human anterior lens capsule in relation to age," Investigative Ophthalmology \& Visual Science, vol. 38, no. 2, pp. 357-363, 1997.

[192] A. Galal, J. J. Perez-Santonja, J. L. Rodriguez-Prats, M. Abad, and J. Alio, "Human anterior lens capsule as a biologic substrate for the ex vivo expansion of limbal stem cells in ocular surface reconstruction," Cornea, vol. 26, no. 4, pp. 473-478, 2007.

[193] R. Albert, Z. Veréb, K. Csomós et al., "Cultivation and characterization of cornea limbal epithelial stem cells on lens capsule in animal material-free medium," PLoS ONE, vol. 7, no. 10, Article ID e47187, 2012.

[194] S. Reichl, M. Borrelli, and G. Geerling, "Keratin films for ocular surface reconstruction," Biomaterials, vol. 32, no. 13, pp. 33753386, 2011.

[195] M. Borrelli, S. Reichl, Y. Feng, M. Schargus, S. Schrader, and G. Geerling, "In vitro characterization and ex vivo surgical evaluation of human hair keratin films in ocular surface reconstruction after sterilization processing," Journal of Materials Science: Materials in Medicine, vol. 24, no. 1, pp. 221-230, 2013.

[196] M. Mohan and S. K. Angra, "Vicryl suture in ophthalmic surgery," Indian Journal of Ophthalmology, vol. 27, no. 3, pp. 2428, 1979.

[197] P. Deshpande, R. McKean, K. A. Blackwood et al., "Using poly(lactide-co-glycolide) electrospun scaffolds to deliver cultured epithelial cells to the cornea," Regenerative Medicine, vol. 5, no. 3, pp. 395-401, 2010.

[198] K. A. Blackwood, R. McKean, I. Canton et al., "Development of biodegradable electrospun scaffolds for dermal replacement," Biomaterials, vol. 29, no. 21, pp. 3091-3104, 2008.

[199] P. Deshpande, C. Ramachandran, V. S. Sangwan, and S. Macneil, "Cultivation of limbal epithelial cells on electrospun poly (lactide-co-glycolide) scaffolds for delivery to the cornea," Methods in Molecular Biology, vol. 1014, pp. 179-185, 2013.

[200] A. Ma, B. Zhao, A. J. Bentley et al., "Corneal epithelialisation on surface-modified hydrogel implants," Journal of Materials Science: Materials in Medicine, vol. 22, no. 3, pp. 663-670, 2011.

[201] S. Rimmer, C. Johnson, B. Zhao et al., "Epithelialization of hydrogels achieved by amine functionalization and co-culture with stromal cells," Biomaterials, vol. 28, no. 35, pp. 5319-5331, 2007.

[202] E. Hassan, P. Deshpande, F. Claeyssens, S. Rimmer, and S. MacNeil, "Amine functional hydrogels as selective substrates for corneal epithelialization," Acta Biomaterialia, vol. 10, no. 7, pp. 3029-3037, 2014.

[203] S. A. Holak, H. M. Holak, and H. Bleckmann, "AlphaCor keratoprosthesis: postoperative development of six patients," Graefe's Archive for Clinical and Experimental Ophthalmology, vol. 247, no. 4, pp. 535-539, 2009.

[204] T. V. Chirila, I. J. Constable, G. J. Crawford et al., "Poly(2hydroxyethyl methacrylate) sponges as implant materials: in vivo and in vitro evaluation of cellular invasion," Biomaterials, vol. 14, no. 1, pp. 26-38, 1993.

[205] A. M. Oelker and M. W. Grinstaff, "Synthesis, characterization, and in vitro evaluation of a hydrogel-based corneal onlay," IEEE Transactions on NanoBioscience, vol. 11, no. 1, pp. 37-45, 2012.

[206] L. Hartmann, K. Watanabe, L. L. Zheng et al., "Toward the development of an artificial cornea: improved stability of interpenetrating polymer networks," Journal of Biomedical Materials Research Part B: Applied Biomaterials, vol. 98, no. 1, pp. 8-17, 2011.

[207] X. W. Tan, L. Hartman, K. P. Tan et al., "In vivo biocompatibility of two PEG/PAA interpenetrating polymer networks as corneal inlays following deep stromal pocket implantation," Journal of Materials Science: Materials in Medicine, vol. 24, no. 4, pp. 967977, 2013.

[208] D. Myung, W. Koh, A. Bakri et al., "Design and fabrication of an artificial cornea based on a photolithographically patterned hydrogel construct," Biomedical Microdevices, vol. 9, no. 6, pp. 911-922, 2007.

[209] B. Ozcelik, K. D. Brown, A. Blencowe, M. Daniell, G. W. Stevens, and G. G. Qiao, "Ultrathin chitosan-poly(ethylene glycol) hydrogel films for corneal tissue engineering," Acta Biomaterialia, vol. 9, no. 5, pp. 6594-6605, 2013.

[210] F. L. Gimeno, V. Lavigne, S. Gatto, J. O. Croxatto, L. Correa, and J. E. Gallo, "Advances in corneal stem-cell transplantation in rabbits with severe ocular alkali burns," Journal of Cataract and Refractive Surgery, vol. 33, no. 11, pp. 1958-1965, 2007.

[211] F. L. Gimeno, V. Lavigne, S. Gatto, J. O. Croxatto, L. Correa, and J. E. Gallo, "One-year follow-up of epithelial corneal cell sheet allografts mounted on platelet poor plasma in rabbits," Molecular Vision, vol. 15, pp. 2771-2779, 2009.

[212] H. Miyashita, S. Shimmura, H. Kobayashi et al., "Collagenimmobilized poly (vinyl alcohol) as an artificial cornea scaffold that supports a stratified corneal epithelium," Journal of Biomedical Materials Research Part B: Applied Biomaterials, vol. 76B, no. 1, pp. 56-63, 2006.

[213] Y. Uchino, S. Shimmura, H. Miyashita et al., "Amniotic membrane immobilized poly(vinyl alcohol) hybrid polymer as an artificial cornea scaffold that supports a stratified and differentiated corneal epithelium," Journal of Biomedical Materials Research-Part B: Applied Biomaterials, vol. 81, no. 1, pp. 201206, 2007.

[214] K. Nishida, M. Yamato, Y. Hayashida et al., "Functional bioengineered corneal epithelial sheet grafts from corneal stem cells expanded ex vivo on a temperature-responsive cell culture surface," Transplantation, vol. 77, no. 3, pp. 379-385, 2004.

[215] G. Sitalakshmi, B. Sudha, H. N. Madhavan et al., "Ex vivo cultivation of corneal limbal epithelial cells in a thermoreversible polymer (Mebiol Gel) and their transplantation in rabbits: an animal model," Tissue Engineering Part A, vol. 15, no. 2, pp. 407415, 2009.

[216] K. Higa, S. Shimmura, N. Kato et al., "Proliferation and differentiation of transplantable rabbit epithelial sheets engineered with or without an amniotic membrane carrier," Investigative Opthalmology \& Visual Science, vol. 48, no. 2, pp. 597-604, 2007.

[217] Q. Ke, X. Wang, Q. Gao et al., "Carrier-free epithelial cell sheets prepared by enzymatic degradation of collagen gel," Journal of Tissue Engineering and Regenerative Medicine, vol. 5, no. 2, pp. 138-145, 2011.

[218] W. Zhang, J. Xiao, C. Li et al., "Rapidly constructed scaffoldfree cornea epithelial sheets for ocular surface reconstruction," 
Tissue Engineering Part C: Methods, vol. 17, no. 5, pp. 569-577, 2011.

[219] V. Holan and E. Javorkova, "Mesenchymal stem cells, nanofiber scaffolds and ocular surface reconstruction," Stem Cell Reviews and Reports, vol. 9, no. 5, pp. 609-619, 2013.

[220] T. Nakamura, K.-I. Endo, L. J. Cooper et al., "The successful culture and autologous transplantation of rabbit oral mucosal epithelial cells on amniotic membrane," Investigative Opthalmology \& Visual Science, vol. 44, no. 1, pp. 106-116, 2003.

[221] H.-C. J. Chen, H.-L. Chen, J.-Y. Lai et al., "Persistence of transplanted oral mucosal epithelial cells in human cornea," Investigative Ophthalmology \& Visual Science, vol. 50, no. 10, pp. 4660-4668, 2009.

[222] S. Krishnan, G. K. Iyer, and S. Krishnakumar, "Culture \& characterisation of limbal epithelial cells \& oral mucosal cells," Indian Journal of Medical Research, vol. 131, no. 3, pp. 422-428, 2010.

[223] S. Gaddipati, R. Muralidhar, V. Sangwan, I. Mariappan, G. Vemuganti, and D. Balasubramanian, "Oral epithelial cells transplanted on to corneal surface tend to adapt to the ocular phenotype," Indian Journal of Ophthalmology, vol. 62, no. 5, pp. 644-648, 2014.

[224] K. Nishida, M. Yamato, Y. Hayashida et al., "Corneal reconstruction with tissue-engineered cell sheets composed of autologous oral mucosal epithelium," The New England Journal of Medicine, vol. 351, no. 12, pp. 1187-1196, 2004.

[225] L. P. K. Ang, T. Nakamura, T. Inatomi et al., "Autologous serumderived cultivated oral epithelial transplants for severe ocular surface disease," Archives of Ophthalmology, vol. 124, no. 11, pp. 1543-1551, 2006.

[226] T. Inatomi, T. Nakamura, N. Koizumi, C. Sotozono, N. Yokoi, and S. Kinoshita, "Midterm results on ocular surface reconstruction using cultivated autologous oral mucosal epithelial transplantation," The American Journal of Ophthalmology, vol. 141, no. 2, pp. 267-275, 2006.

[227] Y. Satake, K. Higa, K. Tsubota, and J. Shimazaki, "Long-term outcome of cultivated oral mucosal epithelial sheet transplantation in treatment of total limbal stem cell deficiency," Ophthalmology, vol. 118, no. 8, pp. 1524-1530, 2011.

[228] T. Nakamura, K. Takeda, T. Inatomi, C. Sotozono, and S. Kinoshita, "Long-term results of autologous cultivated oral mucosal epithelial transplantation in the scar phase of severe ocular surface disorders," British Journal of Ophthalmology, vol. 95, no. 7, pp. 942-946, 2011.

[229] C. Burillon, L. Huot, V. Justin et al., "Cultured autologous oral mucosal epithelial cell sheet (CAOMECS) transplantation for the treatment of corneal limbal epithelial stem cell deficiency," Investigative Ophthalmology and Visual Science, vol. 53, no. 3, pp. 1325-1331, 2012.

[230] C. Sotozono, T. Inatomi, T. Nakamura et al., "Visual improvement after cultivated oral mucosal epithelial transplantation," Ophthalmology, vol. 120, no. 1, pp. 193-200, 2013.

[231] C. Sotozono, T. Inatomi, T. Nakamura et al., "Cultivated oral mucosal epithelial transplantation for persistent epithelial defect in severe ocular surface diseases with acute inflammatory activity," Acta Ophthalmologica, vol. 92, no. 6, pp. e447-e453, 2014.

[232] S. Kolli, S. Ahmad, H. S. Mudhar, A. Meeny, M. Lako, and F. C. Figueiredo, "Successful application of ex vivo expanded human autologous oral mucosal epithelium for the treatment of total bilateral limbal stem cell deficiency," Stem Cells, vol. 32, no. 8, pp. 2135-2146, 2014.
[233] H. Tanioka, S. Kawasaki, K. Yamasaki et al., "Establishment of a cultivated human conjunctival epithelium as an alternative tissue source for autologous corneal epithelial transplantation," Investigative Opthalmology \& Visual Science, vol. 47, no. 9, pp. 3820-3827, 2006.

[234] L. P. K. Ang, H. Tanioka, S. Kawasaki et al., "Cultivated human conjunctival epithelial transplantation for total limbal stem cell deficiency," Investigative Opthalmology \& Visual Science, vol. 51, no. 2, p. 758, 2010.

[235] J. R. S. Ricardo, P. C. Cristovam, P. A. N. Filho et al., “Transplantation of conjunctival epithelial cells cultivated ex vivo in patients with total limbal stem cell deficiency," Cornea, vol. 32, no. 3, pp. 221-228, 2013.

[236] G. Cotsarelis, T.-T. Sun, and R. M. Lavker, "Label-retaining cells reside in the bulge area of pilosebaceous unit: implications for follicular stem cells, hair cycle, and skin carcinogenesis," Cell, vol. 61, no. 7, pp. 1329-1337, 1990.

[237] E. A. Meyer-Blazejewska, M. K. Call, O. Yamanaka et al., "From hair to cornea: toward the therapeutic use of hair follicle-derived stem cells in the treatment of limbal stem cell deficiency," Stem Cells, vol. 29, no. 1, pp. 57-66, 2011.

[238] Q. Zhou, X.-Y. Liu, Y.-X. Ruan et al., "Construction of corneal epithelium with human amniotic epithelial cells and repair of limbal deficiency in rabbit models," Human Cell, vol. 28, no. 1, pp. 22-36, 2015.

[239] K. Zhou, C. Koike, T. Yoshida et al., "Establishment and characterization of immortalized human amniotic epithelial cells," Cellular Reprogramming, vol. 15, no. 1, pp. 55-67, 2013.

[240] G. Pratama, V. Vaghjiani, J. Y. Tee et al., "Changes in culture expanded human amniotic epithelial cells: implications for potential therapeutic applications," PLoS ONE, vol. 6, no. 11, Article ID e26136, 2011.

[241] T. Miki, T. Lehmann, H. Cai, D. B. Stolz, and S. C. Strom, "Stem cell characteristics of amniotic epithelial cells," Stem Cells, vol. 23, no. 10, pp. 1549-1559, 2005.

[242] S. S. Fatimah, S. L. Ng, K. H. Chua, A. R. Hayati, A. E. Tan, and G. C. Tan, "Value of human amniotic epithelial cells in tissue engineering for cornea," Human Cell, vol. 23, no. 4, pp. 141-151, 2010.

[243] J. A. Thomson, J. Itskovitz-Eldor, S. S. Shapiro et al., "Embryonic stem cell lines derived from human blastocysts," Science, vol. 282, no. 5391, pp. 1145-1147, 1998.

[244] S. Ahmad, R. Stewart, S. Yung et al., "Differentiation of human embryonic stem cells into corneal epithelial-like cells by in vitro replication of the corneal epithelial stem cell niche," Stem Cells, vol. 25, no. 5, pp. 1145-1155, 2007.

[245] J. Zhu, K. Zhang, Y. Sun et al., "Reconstruction of functional ocular surface by acellular porcine cornea matrix scaffold and limbal stem cells derived from human embryonic stem cells," Tissue Engineering Part A, vol. 19, no. 21-22, pp. 2412-2425, 2013.

[246] W. Zhang, W. Yang, X. Liu, L. Zhang, W. Huang, and Y. Zhang, "Rapidly constructed scaffold-free embryonic stem cell sheets for ocular surface reconstruction," Scanning, vol. 36, no. 3, pp. 286-292, 2014.

[247] E. Kiskinis and K. Eggan, "Progress toward the clinical application of patient-specific pluripotent stem cells," The Journal of Clinical Investigation, vol. 120, no. 1, pp. 51-59, 2010.

[248] K. Takahashi and S. Yamanaka, "Induction of pluripotent stem cells from mouse embryonic and adult fibroblast cultures by defined factors," Cell, vol. 126, no. 4, pp. 663-676, 2006. 
[249] R. Hayashi, Y. Ishikawa, M. Ito et al., "Generation of corneal epithelial cells from induced pluripotent stem cells derived from human dermal fibroblast and corneal limbal epithelium," PLoS ONE, vol. 7, no. 9, Article ID e45435, 2012.

[250] D. Sareen, M. Saghizadeh, L. Ornelas et al., "Differentiation of human limbal-derived induced pluripotent stem cells into limbal-like epithelium," Stem Cells Translational Medicine, vol. 3, no. 9, pp. 1002-1012, 2014.

[251] K. Kim, A. Doi, B. Wen et al., "Epigenetic memory in induced pluripotent stem cells," Nature, vol. 467, no. 7313, pp. 285-290, 2010.

[252] A. Mikhailova, T. Ilmarinen, H. Uusitalo, and H. Skottman, "Small-molecule induction promotes corneal epithelial cell differentiation from human induced pluripotent stem cells," Stem Cell Reports, vol. 2, no. 2, pp. 219-231, 2014.

[253] H. M. Reza, B.-Y. Ng, F. L. Gimeno, T. T. Phan, and L. P.-K. Ang, "Umbilical cord lining stem cells as a novel and promising source for ocular surface regeneration," Stem Cell Reviews and Reports, vol. 7, no. 4, pp. 935-947, 2011.

[254] I. Garzón, M. A. Martín-Piedra, C. Alfonso-Rodríguez et al., "Generation of a biomimetic human artificial cornea model using Wharton's jelly mesenchymal stem cells," Investigative Opthalmology \& Visual Science, vol. 55, no. 7, pp. 4073-4083, 2014.

[255] Y. Ma, Y. Xu, Z. Xiao et al., "Reconstruction of chemically burned rat corneal surface by bone marrow-derived human mesenchymal stem cells," Stem Cells, vol. 24, no. 2, pp. 315-321, 2006.

[256] S. Gu, C. Xing, J. Han, M. O. M. Tso, and J. Hong, "Differentiation of rabbit bone marrow mesenchymal stem cells into corneal epithelial cells in vivo and ex vivo," Molecular Vision, vol. 15, pp. 99-107, 2009.

[257] T.-S. Jiang, L. Cai, W.-Y. Ji et al., "Reconstruction of the corneal epithelium with induced marrow mesenchymal stem cells in rats," Molecular Vision, vol. 16, pp. 1304-1316, 2010.

[258] H. Reinshagen, C. Auw-Haedrich, R. V. Sorg et al., "Corneal surface reconstruction using adult mesenchymal stem cells in experimental limbal stem cell deficiency in rabbits," Acta Ophthalmologica, vol. 89, no. 8, pp. 741-748, 2011.

[259] C. M. Rohaina, K. Y. Then, A. M. H. Ng et al., "Reconstruction of limbal stem cell deficient corneal surface with induced human bone marrow mesenchymal stem cells on amniotic membrane," Translational Research, vol. 163, no. 3, pp. 200-210, 2014.

[260] J. A. West-Mays and D. J. Dwivedi, “The keratocyte: corneal stromal cell with variable repair phenotypes," The International Journal of Biochemistry \& Cell Biology, vol. 38, no. 10, pp. 16251631, 2006.

[261] M. J. Branch, K. Hashmani, P. Dhillon, D. R. Jones, H. S. Dua, and A. Hopkinson, "Mesenchymal stem cells in the human corneal limbal stroma," Investigative Opthalmology \& Visual Science, vol. 53, no. 9, pp. 5109-5116, 2012.

[262] K. Hashmani, M. J. Branch, L. E. Sidney et al., "Characterization of corneal stromal stem cells with the potential for epithelial transdifferentiation," Stem Cell Research \& Therapy, vol. 4, no. 3, article 75, 2013.

[263] T. Nieto-Miguel, S. Galindo, R. Reinoso et al., "In vitro simulation of corneal epithelium microenvironment induces a corneal epithelial-like cell phenotype from human adipose tissue mesenchymal stem cells," Current Eye Research, vol. 38, no. 9, pp. 933-944, 2013.

[264] B. G. Monteiro, R. C. Serafim, G. B. Melo et al., "Human immature dental pulp stem cells share key characteristic features with limbal stem cells," Cell Proliferation, vol. 42, no. 5, pp. 587-594, 2009.

[265] N. Zakaria, S. Van Grasdorff, K. Wouters et al., "Human tears reveal insights into corneal neovascularization," PLOS ONE, vol. 7, no. 5, Article ID e36451, 2012.

[266] E. L. Davies and M. T. Fuller, "Regulation of self-renewal and differentiation in adult stem cell lineages: lessons from the Drosophila male germ line," Cold Spring Harbor Symposia on Quantitative Biology, vol. 73, pp. 137-145, 2008. 

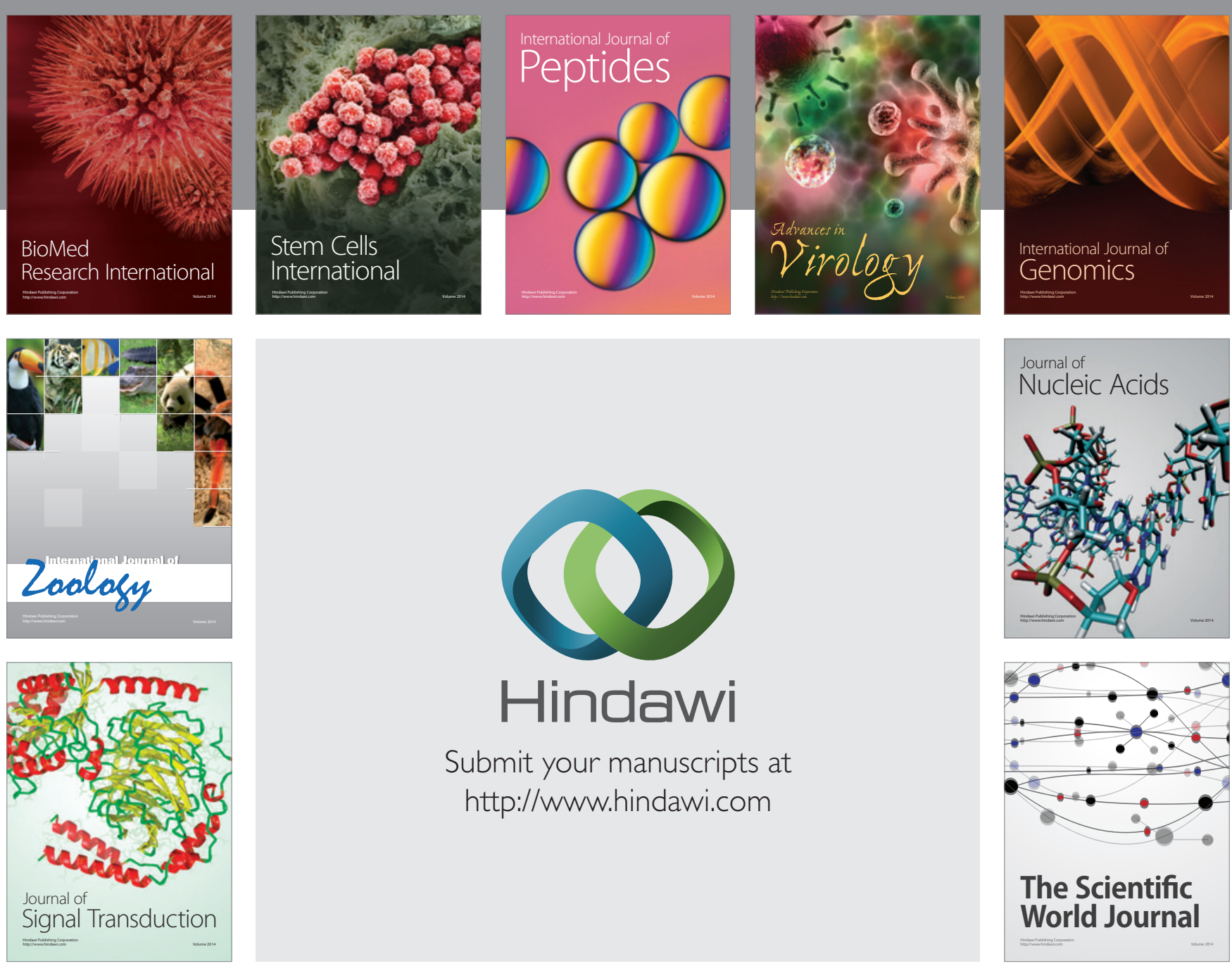

Submit your manuscripts at

http://www.hindawi.com
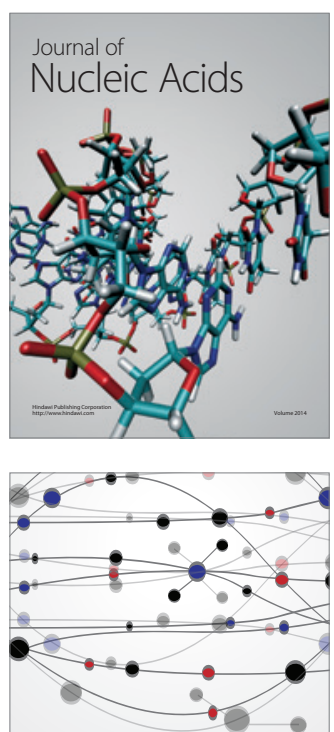

The Scientific World Journal
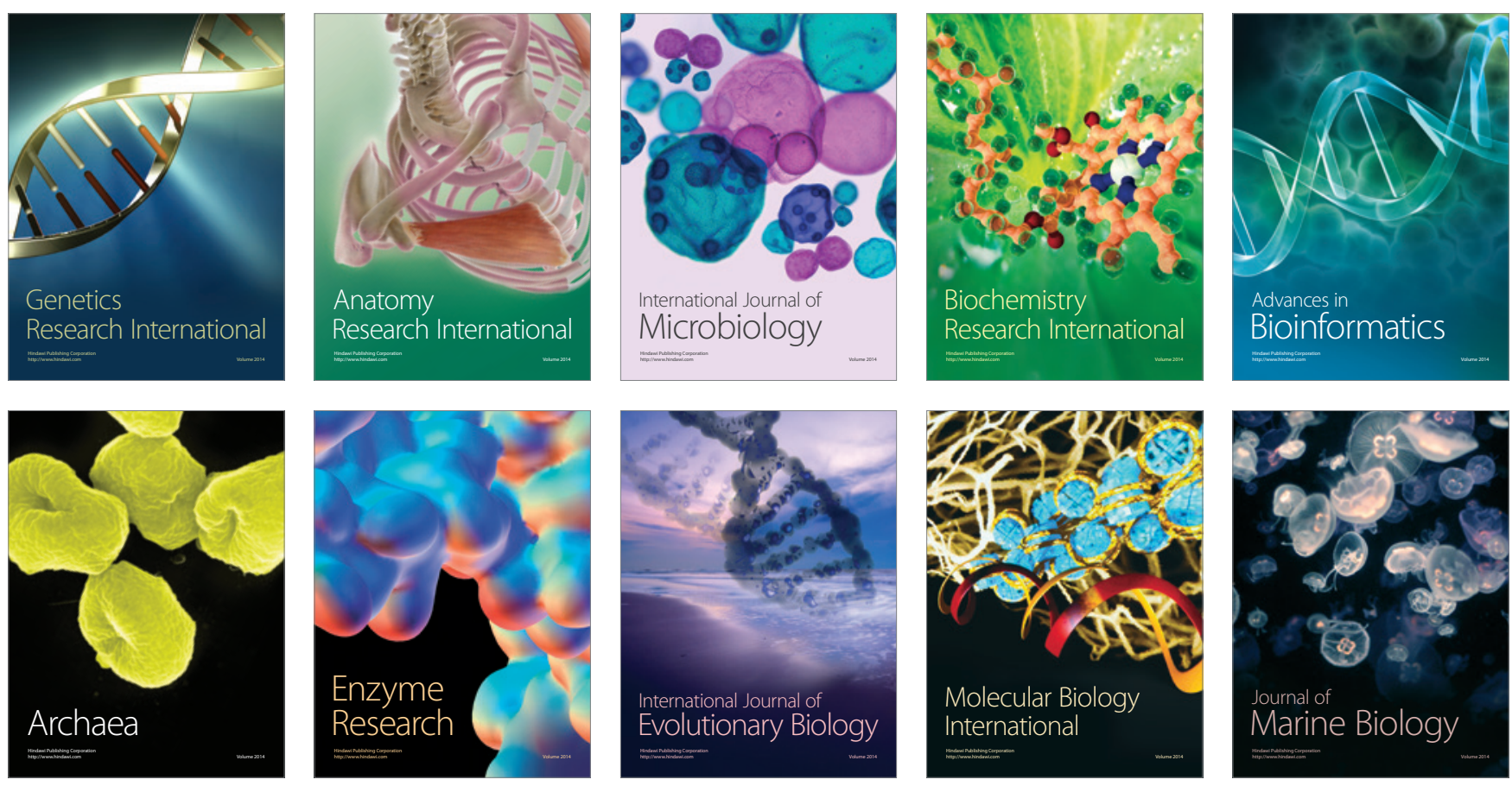